\title{
Summer Outdoor Thermal Benchmarks in Melbourne: Applications of Different Techniques.
}

Inji Kenawy ${ }^{a}$, Cho Kwong Charlie Lam ${ }^{b, c}$, Salman Shooshtarian ${ }^{d}$

${ }^{a}$ School of Science, Engineering and Environment, University of Salford, Manchester, UK

${ }^{b}$ School of Atmospheric Sciences, Guangdong Province Key Laboratory for Climate Change and Natural Disaster Studies, Sun Yat-sen University, Guangzhou, China

${ }^{c}$ Southern Marine Science and Engineering Guangdong Laboratory (Zhuhai), Zhuhai, China

${ }^{d}$ School of Property, Construction and Project Management, RMIT University, Melbourne, Australia

\begin{abstract}
In urban planning, sustainability is often synonymous to urban livability. Urban livability seeks to improve living conditions of current and future outdoor users and hence it has become a key priority for cities authorities. Melbourne, as the world second most livable city, sets out to improve its urban life quality through various policies and initiatives. One area of improvement is the creation of sustainable outdoor spaces that provides comfortable thermal conditions for its residents. The relevant strategies to create such spaces are supported by the knowledge of human thermal comfort requirements, particularly during the summer thermal conditions. Hence, this study aims to develop comprehensive thermal comfort benchmarks for Melbourne during the summer. This study builds on 4717 subjective survey responses collected in seven urban environments with different settings. Data collection was performed in Melbourne's summer from 2012 to 2015. Physiological Equivalent Temperature (PET) was used to predict thermal comfort conditions. The results were based on four thermal comfort measures (neutral temperature,
\end{abstract}


preferred temperature, acceptable thermal range and thermal comfort range). These outcomes of the analysis suggested that Melbourne summer acceptable thermal range is between $11.3^{\circ} \mathrm{C}$ and $20.3^{\circ} \mathrm{C}$, the preferred temperature value is $21.5^{\circ} \mathrm{C}$, the neutral temperature value is $16.1^{\circ} \mathrm{C}$. Furthermore, PET index was calibrated against thermal responses collected from the field studies. The results would help to inform policies aiming to create sustainable and thermally comfortable outdoor spaces that are pleasant to outdoor users in Melbourne city.

Keywords: Summer thermal comfort, human thermal comfort, physiological equivalent temperature (PET), calibration and benchmarking, sustainable outdoor spaces, outdoor thermal comfort, urban livability

\section{Introduction}

In urban studies context, sustainability is synonymous to urban livability. Improving urban livability in cities has become a key priority for cities [1]. Livability refers to various constructed views about the quality of life in any human living environment [2]. Currently, there is fierce competition among cities to place themselves among the most livable cities in the world. The title is believed to create several economic, social, and environmental benefits.

The most comprehensive urban livability ranking tool is The Global Livability Index (GLI) that is operated by The Economist Intelligence Unit (2019) [1]. GLI assessed the cities' quality of life based on five major categories, namely stability, healthcare, culture and environment, education, and infrastructure. Melbourne, capital of Victoria state, was ranked as the most livable for seven years in a row from 2011 to 2017 since after until now Vienna has owned the rank [1]. Being the second most populated city in Australia after Sydney, Melbourne is known as the Australian capital of art, culture, and sport. Since the mid-1990s, this city has maintained substantial population and employment growth. The city is a sought-after migration target for many migrants across Australia 
and the world. In December 2019, 61.4\% of annual population growth was attributed to net migration ( $7.6 \%$ interstate, $53.8 \%$ overseas) [3]. Melbourne is a popular tourist destination for many travel makers featuring several attractions.

Despite the mass urbanisation in the Melbourne city centre [4], this city has retained its historical character that is known as Victorian heritage. Victoria heritage is of cultural significance to the State of Victoria and its residents [5,6]. Federation Square is a main attraction in the Melbourne Central Business District (CBD); it is a landmark for tourists to visit as well as a spot for public activities events that are frequently organised. Melbourne is also known for its twin royal botanical gardens (Melbourne and Cranbourne); they are universally recognised as one of the world most beautiful and stunning botanical landscapes [7]. For 170 years they have been home to a diverse collection of plants. The city is also the home to several internationally recognised educational and research institutions that attract several thousand international students each year [8,9]. In December 2019, Australia hosted 758,154 international students [10] of which about 35\% belonged to the state of Victoria and mostly studied in Melbourne. The sustainable economy in Melbourne is equal to the sustainable influx of migrants, tourists, and prospective international students.

In efforts to reclaim its title, Melbourne has now set out to do what it takes to firstly remain competitive and secondly improve its living quality [11]. Accordingly, the city has set various policies, initiatives, and developments [12-14]. Among other improvements, outdoor urban quality is deemed to be a determining factor [14]. The thermal conditions of outdoor spaces are among top reasons that individuals consider when deciding on migration [15], holiday making [15, 16], and study. Melbourne has a temperate oceanic climate $(\mathrm{Cfb})$ with highly variable weather 
conditions [17]. However, in recent years Melburnians have witnessed undesirable weather conditions throughout summer that are typically exacerbated with heatwaves. This weather conditions cause thermal discomfort indoors and outdoors. According to the climate change projections in Australia, urban heat stress conditions are going to be more frequent and extended in future in Melbourne [18].

Several strategies could assist urban designers and planners by providing thermally comfortable outdoors [19]. However, successful implementation of these strategies largely hinges on our knowledge of people thermal comfort requirements. There are a few studies that previously evaluated and predicted people thermal comfort requirements in Melbourne summer [20-23]. However, these studies were conducted in different urban settings and had varied targeted populations. While the datasets emerged from these studies provide valuable information, their aggregation allows for more powerful insight into thermal comfort requirements.

Comfort data aggregation dates to $20^{\text {th }}$ century when the first global database was created through an international project called the ASHRAE Thermal Comfort Database I [24], an effort that was reiterated in 2018, under the ASHRAE Thermal Comfort Database II project [25]. These projects combined indoor comfort data obtained worldwide and contributed to developing adaptive thermal comfort model. Other studies took the same approach to empower comfort data for indoor context $[26,27]$. In outdoor settings, the first attempt to aggregate comfort data was made under Rediscovering the Urban Realm and Open spaces (RUROS) project [28]. This study accumulated the data collected from seven European cities and subsequently created the first European outdoor thermal comfort benchmark. The benchmark is still in use to evaluate thermal comfortability of urban open spaces. There have been a few other attempts with similar objectives in thermal comfort 
research communities $[29,30]$. As climate conditions are strictly related to local population. A wide portion of research has been devoted to finding indexes about local climate, and universal climate indices have been proposed on the other hand [31, 32].

In various studies, different benchmarking techniques are used to determine outdoor thermal comfort conditions. A benchmark is mostly indexed by neutral temperature, preferred temperature and acceptable thermal range $[21,33,34]$. Neutral temperature is a temperature value at which most people feel neither cool nor warm, the acceptable thermal range is a condition in which a large number of people accept thermal conditions, and the preferred temperature is a temperature value at which people require no change in the current weather conditions. This study attempted to explore the three main thermal comfort benchmarking indicators using Melbourne as a case study to demonstrate how different techniques could affect the results of thermal benchmarks.

Furthermore, many outdoor thermal comfort studies have focused on limited sites in a city, which might not be representative of various urban forms in a city. Some recent studies have examined outdoor thermal comfort in different urban settings in a city using the local climate zone (LCZ) scheme $[35,36]$. In this context, this study aims to develop a comprehensive outdoor thermal comfort benchmark in Melbourne during the summer. The study builds on the comfort data collected in three previous studies [37-39] that were conducted between 2012 and 2015, which include various urban forms ranging from urban parks, university campuses, public squares to the central business district.

\section{Methodology}


As previously mentioned, the analysis of this paper resulted from three studies that took place in Melbourne city. The three studies considered both objective field measurements and subjective human assessments. The field measurements involved monitoring the micrometeorological involved in calculating the thermal index. Structured questionnaires and observations took place in parallel to the field measurements, which have been employed in previous studies [40, 41].

\subsection{Study sites}

The first study involved an urban square and a university campus. These were the Federation Square in the CBD, and Deakin University Burwood Campus shown in Figure 1 as site 1-A and site 1-B. The total area of the square is 3.2 hectares, and it is considered a main place for people to gather as it could accommodate 15000 people at one time. Its special location between key buildings and intersections, allowed it to be one of the main attractions in the CBD. The square's flooring is paved with sandstone cobblestones with very few scattered trees. Unlike the Federation Square, Deakin University, Burwood Campus, is around $15 \mathrm{~km}$ away from the CBD. The campus accommodates around 20800 students. The main spine in the campus is paved with concrete, in addition to numerous green areas.

The second study was concerned with the botanic gardens: Melbourne Gardens (opened in 1846) and Cranbourne Gardens (opened in 2006) (see site 2-A and 2-B in Figure 1). The Melbourne Gardens are in South Yarra, which is near the CBD of Melbourne, with a N-S orientation. The Melbourne Gardens cover 38 hectares and includes a variety of native Australian and foreign species from various habitats and countries. The Cranbourne Gardens are located at $45 \mathrm{~km}$ southeast of Melbourne with a N-S orientation. It has a 15 ha 'Australian Garden' that has a variety of native Australian vegetation. Moreover, the Australian Garden differs from Melbourne Gardens 
in terms of its landscape design and vegetation species. The sky view factor (SVF) levels are between 0.027 and 0.859 in the Melbourne Gardens, and $0.356-1.000$ in the Australian Garden. The Melbourne Gardens are covered by lawn areas, asphalt pavement, scattered low-rise buildings and an ornamental lake. In comparison, the Australian Garden is covered by sand, pervious mulch, slate paving stones, scattered lawn area, low-rise buildings and artificial lakes.

The third study was concerned with three open spaces situated in an educational precinct (RMIT University City Campus) in Melbourne's CBD (Figure 1). These sites featured various design specifications that impacted the level of light exposure during the day. Various areas identified in the study sites include access pavements (paths to adjacent educational buildings), sports courts, recreational facilities, such as sitting areas and decks, and parking lots. Depending on the existing shading obstacles, time of day and season, these areas were exposed to the sun or shaded at various times. These open spaces, which are oriented NW-SE, feature the aspect ratios $(\mathrm{H} / \mathrm{W})$ between 1.8 and 2.8 , the SVF levels between 0.206 and 0.458 , and are primarily covered by cobblestone, concrete asphalt, asphalt, timber deck, artificial turf, green spaces, and exposed concrete aggregate. Other relevant information on study open spaces is provided in Table 1.

Table 1 Features of study sites

\begin{tabular}{|c|c|c|c|c|}
\hline \multicolumn{2}{|c|}{ Study sites } & Description & Data and time & Target populations \\
\hline 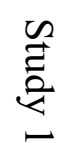 & Site 1-A: FS & $\begin{array}{l}\text { Federation square } \\
\text { (3.2 hectares) }\end{array}$ & $\begin{array}{lr}\text { January } & \& \\
\text { February } & 2012- \\
2014 & \end{array}$ & City centre outdoor users \\
\hline & Site 1-B: BC & Burwood Campus & $\begin{array}{lr}\text { January } & \& \\
\text { February } & 2012- \\
2014 & \end{array}$ & $\begin{array}{l}\text { Students, university } \\
\text { academics and professional } \\
\text { staff, and other campus } \\
\text { visitors. }\end{array}$ \\
\hline$\stackrel{\mathscr{N}}{\Xi}$ & Site 2-A: RBGV & $\begin{array}{l}\text { Melbourne Gardens } \\
\left(38,000 \mathrm{~m}^{2}\right)\end{array}$ & February 2014 & Garden visitors \\
\hline
\end{tabular}




\begin{tabular}{|c|c|c|c|c|}
\hline & $\begin{array}{l}\text { Site 2-B: } \\
\text { RBGV }\end{array}$ & $\begin{array}{l}\text { Cranbourne Gardens } \\
\left(15,000 \mathrm{~m}^{2}\right)\end{array}$ & January 2014 & Garden visitors \\
\hline \multirow{3}{*}{ 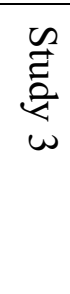 } & Site 3-A: RUCC & $\begin{array}{l}\text { University lawn } \\
\left(1,473 \mathrm{~m}^{2}\right)\end{array}$ & February 2015 & \multirow{3}{*}{$\begin{array}{l}\text { Students, university } \\
\text { academic and professional } \\
\text { staff, and others }\end{array}$} \\
\hline & Site 3-B: RUCC & $\begin{array}{l}\text { Ellis court } \\
\left(1,302 \mathrm{~m}^{2}\right)\end{array}$ & February 2015 & \\
\hline & Site 3-C: RUCC & $\begin{array}{l}\text { Urban square } \\
\left(2,800 \mathrm{~m}^{2}\right)\end{array}$ & February 2015 & \\
\hline
\end{tabular}
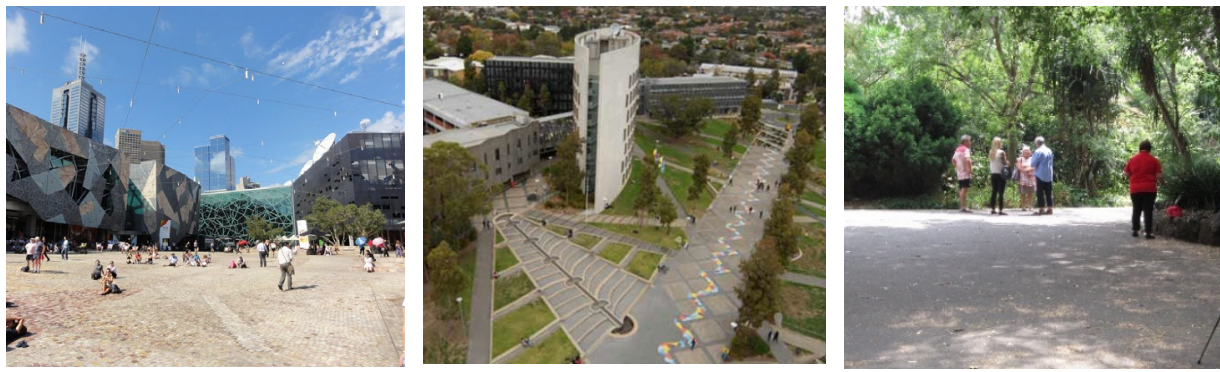

$(1-\mathrm{A})$

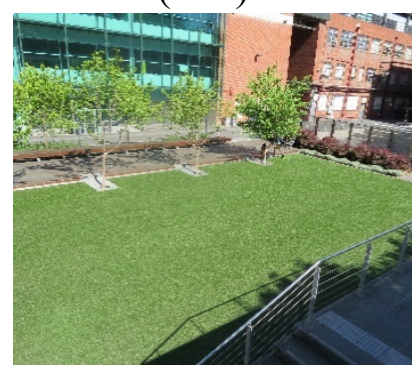

$(3-\mathrm{A})$

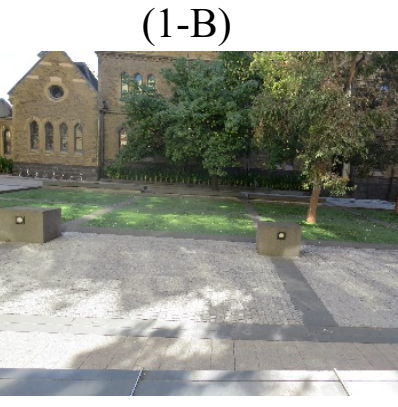

$(3-B)$

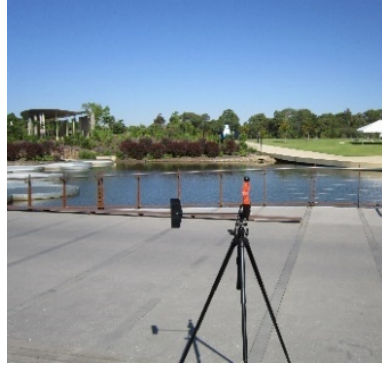

$(2-B)$

Figure 1 Study sites overview

\subsection{Survey}

The randomly distributed surveys aimed to assess the human thermal sensation within the different case studies. The surveys from the first case study were collected between January and February 2012 and 2014 from 9:00 am to 5:00 pm. For the second case study, we conducted the surveys between January and February 2014 from 10:00 am to 3:00pm. In the third case study data were 
collected in February 2015 from 9:00 am to 5:00 pm. All three studies focus on the summer data (January to February) collected in different years.

The surveys included demographic details (i.e., age, gender, climate background), and the characteristics of outdoor usage (i.e., activities, length of stay, thermal history). Then the respondents were asked to select their thermal sensation according to the ASHRAE 7-point scale. Finally, the respondents were asked if they preferred the climate to be cooler, warmer or the same, as per the McIntyre 3-point scale. More variables were included in study 1 and 3, including thermal acceptability and comfortability. However, as all three studies have used the same thermal sensation and thermal preference scales, these were the results that were able to be combined and analysed collaboratively.

\subsection{Microclimate conditions}

The specifications and the accuracy of the instruments used in the three studies are presented in Table 2. In the first study, two Mobile Architecture and Built Environment Laboratory (Mabel) thermal comfort carts with Campbell Scientific CR23X data logger, were used to monitor the micrometeorological parameters. These carts were selected given their high accuracy and mobility. They measured ambient air temperature $\left(\mathrm{T}_{\mathrm{a}}\right.$ in $\left.{ }^{\circ} \mathrm{C}\right)$, relative humidity $(\mathrm{RH}$ in $\%)$, wind speed $(\mathrm{V}$ in $\mathrm{m} / \mathrm{s}$ ), and globe temperature $\left(\mathrm{T}_{\mathrm{g}}\right.$ in $\left.{ }^{\circ} \mathrm{C}\right)$ at different heights at 1 - and 15 -minutes intervals. These heights correspond to the ankles, waist, head of a seated person, as well as the head of a standing person. The thermal environments were assessed according to the procedures and protocols prescribed in ASHRAE's thermal comfort standard- ASHRAE [42] and ISO 7726 [43]. 
In the Melbourne Gardens and Cranbourne Gardens (study 2), the Campbell Scientific CR211X loggers and Kestrel 4400 heat stress trackers we used to monitor air temperature $\left(\mathrm{T}_{\mathrm{a}}\right.$ in $\left.{ }^{\circ} \mathrm{C}\right)$, relative humidity $\left(\mathrm{RH}\right.$ in $\%$ ), wind speed $(\mathrm{V}$ in $\mathrm{m} / \mathrm{s})$, and globe temperature $\left(\mathrm{T}_{\mathrm{g}}\right.$ in $\left.{ }^{\circ} \mathrm{C}\right)$. The data were averaged into the 10-minute intervals. The $\mathrm{T}_{\mathrm{g}}$ was measured by black globe thermometers (150mm for Campbell Scientific station and 25-mm for Kestrel 4400 heat stress trackers).

The protocol for measurement in the third study, including the measuring range and the accuracy of the instruments was in 100\% compliance with ASHRAE [42] and ISO 7730 [44]. The environmental parameters were measured using a portable Testo 480 IAQ Pro Measurement Kit. The measurement kit was placed close to the participants, within a radius of $2 \mathrm{~m}$, while they were responding to the survey. The data recording was synchronised, and one-minute sampling frequency was applied. The readings were logged by a Testo480 data logger and H21-002- HOBO Micro Station.

The mean radiant temperature $\left(T_{m r t}\right)$ for all the studies was calculated using Eq. (1) [45].

$T_{m r t}=\left[\left(T_{g}+273.15\right)^{4}+\frac{1.1 \times 10^{8} v^{0.6}}{\varepsilon D^{0.4}} \times\left(T_{g}-T_{a}\right)\right]^{1 / 4}-273.1$

Where $T_{g}$ is the globe temperature $\left({ }^{\circ} \mathrm{C}\right) ; T_{a}$ is the air temperature $\left({ }^{\circ} \mathrm{C}\right) ; v$ is the wind speed $(\mathrm{m} / \mathrm{s})$; $D$ is the globe diameter $(\mathrm{m})$, and $\varepsilon$ is the globe emissivity ( 0.95 for black globe).

\subsection{Data processing and analysis}

Outdoor thermal comfort surveys were conducted in parallel to meteorological measurements by automatic weather stations. After that, we matched the time of survey with the weather data recorded at the same time, which allowed us to evaluate people's thermal perception at that time. 
From the data collected in the three research projects, this study only used data on demographic details (i.e. gender), metabolic rate, clothing, thermal sensations, and thermal preferences. Four variables of RH, $\mathrm{T}_{\mathrm{a}}, \mathrm{V}$, and $T_{m r t}$ yielded from the physical measurements conducted in the three studies were used to estimate the Physiological Equivalent Temperature (PET) which is the commonly used index for outdoor thermal comfort. The data obtained from the field surveys were screened and analysed using Microsoft Excel Spreadsheets V. 2010 and SPSS V.22.

Inferential analysis was employed to determine the strength of association between the predictors of thermal sensation under various thermal conditions. Hence, regression models [78], Pearson (for continuous dependent variable), and Spearman's rank (for categorical dependent variables) correlation tests were used. Probit analysis was also used to determine the preferred temperature. 
Table 2 Specifications of the climate equipment used in the three studies

\begin{tabular}{|c|c|c|c|c|c|c|c|c|}
\hline & \multicolumn{2}{|c|}{ Study 1} & \multicolumn{3}{|c|}{ Study 2} & \multicolumn{3}{|c|}{ Study 3} \\
\hline $\begin{array}{l}\text { Measured } \\
\text { parameter }\end{array}$ & Logger & $\begin{array}{l}\text { Accuracy and } \\
\text { resolution }\end{array}$ & Logger & $\begin{array}{l}\text { Measuring } \\
\text { range }\end{array}$ & $\begin{array}{l}\text { Accuracy } \\
\text { and } \\
\text { resolution } \\
\end{array}$ & Logger & $\begin{array}{c}\text { Measuring } \\
\text { range }\end{array}$ & $\begin{array}{l}\text { Accuracy and } \\
\text { resolution }\end{array}$ \\
\hline $\begin{array}{l}\text { Air temperature } \\
\left({ }^{\circ} \mathrm{C}\right)\end{array}$ & $\begin{array}{l}3 \text { x OMEGA } \\
44032 \text { linear } \\
\text { thermistor } \\
\text { composite }\end{array}$ & $\begin{array}{l}\text { - } \\
\text { interchangeability } \\
\pm 0.1^{\circ} \mathrm{C} \\
\text { - time constant } 1 \\
\text { sec }\end{array}$ & $\begin{array}{lr}\text { CR211X: } & \text { Vaisala } \\
\text { HUMICAP } & \\
\text { Humidity } & \text { and } \\
\text { Temperature } & \text { Probe } \\
\text { HMP155 } & \end{array}$ & $\begin{array}{l}-80^{\circ} \mathrm{C} \text { to } \\
60^{\circ} \mathrm{C}\end{array}$ & $\begin{array}{l} \pm \quad 0.17^{\circ} \mathrm{C} \\
\text { [Accuracy } \\
\text { with voltage } \\
\text { output at } \\
20^{\circ} \mathrm{C} \text { ] }\end{array}$ & $\begin{array}{ll}\text { TESTO } & \text { IAQ } \\
\text { probe } & 0632 \\
1543 & \end{array}$ & $0{ }^{\circ} \mathrm{C}$ to $50^{\circ} \mathrm{C}$ & $\begin{array}{l} \pm 0.5^{\circ} \mathrm{C} \text { (at the } \\
\text { temperature of } \\
\left.22^{\circ} \mathrm{C}\right) ; 0.1^{\circ} \mathrm{C}\end{array}$ \\
\hline & & & $\begin{array}{l}\text { K4400: Hermetically } \\
\text { sealed, precision } \\
\text { thermistor mounted } \\
\text { externally and } \\
\text { thermally isolated for } \\
\text { rapid response }\end{array}$ & $\begin{array}{l}-29^{\circ} \mathrm{C} \text { to } \\
70^{\circ} \mathrm{C}\end{array}$ & $\pm 1^{\circ} \mathrm{C}$ & & & \\
\hline $\begin{array}{l}\text { Relative } \\
\text { humidity (\%) }\end{array}$ & $\begin{array}{l}\text { HyCal } \\
\text { integrated } \\
\text { circuithumidity } \\
\text { sensor (IH- } \\
3605-\mathrm{B})\end{array}$ & $\begin{array}{l}\text { - repeatability } \pm \\
0.5 \% \text { rh at } 25^{\circ} \mathrm{C} \\
- \text { total accuracy } \pm \\
2 \% \text { rh at } 25^{\circ} \mathrm{C} \\
-\quad \text { hysteresis } \pm \\
0.8 \% \text { of span max } \\
\text { - time constant } 15 \\
\text { sec at } 25^{\circ} \mathrm{C}\end{array}$ & $\begin{array}{lr}\text { CR211X: } & \text { Vaisala } \\
\text { HUMICAP® } & \\
\text { Humidity } & \text { and } \\
\text { Temperature } & \text { Probe } \\
\text { HMP155 } & \end{array}$ & 0 to $100 \%$ & 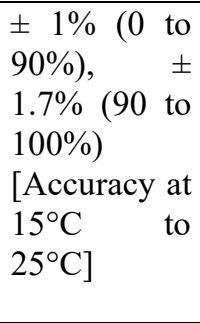 & $\begin{array}{ll}\text { TESTO } & \text { IAQ } \\
\text { probe } & 0632 \\
1543 & \end{array}$ & $\begin{array}{l}0 \text { to }+100 \\
\% \mathrm{RH} \quad \text { (non- } \\
\text { condensing) }\end{array}$ & $\begin{array}{l} \pm \\
\% \mathrm{RH}+0.7 \% \text { of } \\
\text { meas. Val.) and } \\
\pm 0.03 \% \mathrm{RH} / \mathrm{K} \\
\left.\text { (based on } 25{ }^{\circ} \mathrm{C}\right) ; \\
0.1 \% \mathrm{RH}\end{array}$ \\
\hline & & & $\begin{array}{l}\text { K4400: } \quad \begin{array}{l}\text { Polymer } \\
\text { capacitive }\end{array} \text { sensor, } \\
\text { mounted externally in } \\
\text { thin-walled chamber. }\end{array}$ & 5 to $95 \%$ & $\pm 3 \%$ & & & \\
\hline Wind speed $(\mathrm{m} / \mathrm{s})$ & $\begin{array}{l}3 \times \text { Digital TSI } \\
\text { omnidirectional } \\
\text { anemometers } \\
\text { (model number } \\
8475 \text { ) }\end{array}$ & $\begin{array}{l}\text { - Time constant } \\
\text { adjustable } 0.2 \text { to } 2 \\
\text { sec with default } \\
\text { setting } 0.2 \text { sec. } \\
\text { - range }=0.05-2.5 \\
\mathrm{~m} / \mathrm{s} \\
\text { - accuracy }=3 \% \\
\text { of reading }\end{array}$ & $\begin{array}{l}\text { CR211X: Met One } \\
\text { 014A-L Anemometer }\end{array}$ & 0 to $45 \mathrm{~m} / \mathrm{s}$ & $\begin{array}{l}0.11 \mathrm{~m} / \mathrm{s} \text { or } \\
1.5 \%\end{array}$ & $\begin{array}{l}\text { TESTO } \\
\text { COMFORT } \\
\text { probe } \quad 0628 \\
0143\end{array}$ & 0 to $5 \mathrm{~m} \cdot \mathrm{s}^{-1}$ & $\begin{array}{l}0.5^{\circ} \mathrm{C} \pm(0.03 \mathrm{~m} / \mathrm{s} \\
+4 \% \text { of meas. } \\
\text { Val. }) ; 0.01 \mathrm{~m} . \mathrm{s}-1\end{array}$ \\
\hline
\end{tabular}




\begin{tabular}{|c|c|c|c|c|c|c|c|c|}
\hline & & & $\begin{array}{l}\text { K4400: Impeller - } \\
\text { Diameter } 25 \mathrm{~mm} \text {, high } \\
\text { precision axle and } \\
\text { low-friction Zytel } \AA \\
\text { bearings. }\end{array}$ & 0.6 to $40 \mathrm{~m} / \mathrm{s}$ & $\begin{array}{l} \pm 3 \% \text { of } \\
\text { reading or } \pm \\
0.1 \mathrm{~m} / \mathrm{s}\end{array}$ & & & \\
\hline \multirow[t]{2}{*}{$\begin{array}{l}\text { Globe } \\
\text { temperature }\left({ }^{\circ} \mathrm{C}\right)\end{array}$} & $\begin{array}{l}3 \quad \mathrm{x} \text { OMEGA } \\
44032 \text { linear } \\
\text { thermistor }\end{array}$ & $\begin{array}{l}- \\
\text { interchangeability } \\
\pm 0.1^{\circ} \mathrm{C} \\
-\quad \text { time constant } \\
\text { circa } 10 \text { minutes }\end{array}$ & $\begin{array}{l}\text { CR211X: } 150 \mathrm{~mm} \\
\text { black } \\
\text { thermometer, copper, } \\
\text { externally mounted, } \\
\text { consisting of a } \\
\text { thermocouple wire } \\
\text { (44007 Thermistor) }\end{array}$ & $\begin{array}{l}-80^{\circ} \mathrm{C} \quad \text { to } \\
150^{\circ} \mathrm{C}\end{array}$ & $\begin{array}{l} \pm \quad 0.2^{\circ} \mathrm{C} \\
{[\text { Accuracy at }} \\
0^{\circ} \mathrm{C} \text { to } 70^{\circ} \mathrm{C} \text { ] }\end{array}$ & $\begin{array}{l}\text { TESTO } \\
\text { Globe } \\
\text { thermometer } \\
06020743\end{array}$ & $\begin{array}{ll}0^{\circ} \mathrm{C} & \text { to } \\
+120^{\circ} \mathrm{C}\end{array}$ & $\begin{array}{lll}\text { Class } 1 & (-40 \text { to } \\
+1000 & \left.{ }^{\circ} \mathrm{C}\right) ; 0.1 \\
{ }^{\circ} \mathrm{C} & \end{array}$ \\
\hline & & & $\begin{array}{lr}\text { K4400: } 25 \mathrm{~mm} \text { black } \\
\text { globe thermometer, } \\
\text { copper, externally } \\
\text { mounted. Calibrated } \\
\text { to achieve same } \\
\text { measurements } \\
\begin{array}{l}\text { standard } 150 \\
\text { globe }\end{array}\end{array}$ & $\begin{array}{c}-29^{\circ} \mathrm{C} \text { to } \\
60^{\circ} \mathrm{C}\end{array}$ & $\pm 1.4^{\circ} \mathrm{C}$ & & & \\
\hline $\begin{array}{l}\text { Radiation } \\
\text { intensity Short- } \\
\text { wave radiation } \\
(\mathbf{w} / \mathrm{m} 2)\end{array}$ & & & & & & $\begin{array}{l}\text { The S-LIB- } \\
\text { M003 Sensor }\end{array}$ & $\begin{array}{l}0 \quad \text { to } \\
\mathrm{W} / \mathrm{m} 2\end{array}$ & $\begin{array}{l}\text { Typically, within } \\
\pm 10 \mathrm{~W} / \mathrm{m} 2 \text { or } \pm \\
5 \% ; 1.25 \mathrm{~W} / \mathrm{m} 2\end{array}$ \\
\hline
\end{tabular}




\section{Results}

\subsection{Field measurement and comfort index}

The measured micrometeorological parameters in the different case studies showed a great variation. The frequency for the measured temperature values varied between a minimum of $15.8^{\circ} \mathrm{C}$ to $40.63^{\circ} \mathrm{C}$. According to the PET classification values for Melbourne city [21], these values varied between slightly cool and very hot thermal sensation. The measured relative humidity ranged between $14.6 \%$ to $99.9 \%$. The wind speed varied from 0 to $4.7 \mathrm{~m} / \mathrm{s}$. This is a wide range of measurements which allowed assessing human thermal sensation votes under different climatic conditions within Melbourne. PET is also calculated as the thermal comfort index in this study using Rayman software, version 2.1. The minimum and maximum values for the micrometeorological parameters in each case study is shown in Table 3.

Table 3 Distribution of micrometeorological parameters in the different case studies

\begin{tabular}{|l|l|l|l|l|l|l|l|l|}
\hline \multirow{2}{*}{$\begin{array}{l}\text { Studied } \\
\text { areas }\end{array}$} & \multicolumn{2}{|c|}{ Air temperature ${ }^{\circ} \mathrm{C}$} & \multicolumn{2}{c|}{$\begin{array}{c}\text { Relative humidity } \\
\%\end{array}$} & \multicolumn{1}{|c|}{$\min$} & \multicolumn{2}{c|}{ Wind Speed m/s } & \multicolumn{2}{c|}{ PET ${ }^{\circ} \mathrm{C}$} \\
\cline { 2 - 9 } & $\min$ & \multicolumn{1}{|c|}{$\min$} & $\max$ & Min & $\max$ & $\min$ & $\max$ \\
\hline $1-\mathrm{A}$ & 19.3 & 26.8 & 34.8 & 82.9 & 0.2 & 0.78 & 17.3 & 31 \\
\hline $1-\mathrm{B}$ & 18.2 & 34.6 & 8.4 & 84.5 & 0.3 & 2 & 15.9 & 37 \\
\hline $2-\mathrm{A}$ & 15.8 & 40.6 & 14.6 & 99.9 & 0 & 3.6 & 11.8 & 51.5 \\
\hline $2-\mathrm{B}$ & 16.9 & 39.4 & 18.1 & 95.1 & 0 & 3.7 & 17.5 & 55.6 \\
\hline $3-\mathrm{A}$ & 18.8 & 27.3 & 40.2 & 72.5 & 0.5 & 3.9 & 14.9 & 30.4 \\
\hline $3-\mathrm{B}$ & 23 & 34.5 & 28.2 & 72.5 & 0.3 & 3.4 & 20.6 & 42.1 \\
\hline $3-\mathrm{C}$ & 19.6 & 29.1 & 37.4 & 80.9 & 0.2 & 4.7 & 16.4 & 34.1 \\
\hline
\end{tabular}

\subsection{Respondents characteristics}

A total of 4717 surveys were collected during summer 2012 - 2015 across the three studies. The gender distribution for the respondents is shown in Table 4 and Figure 2. 
Table 4 Distribution of respondents in the different studied areas

\begin{tabular}{|l|l|l|l|l|l|l|l|l|l|l|l|l|l|l|l|}
\hline & \multicolumn{2}{|l}{ Site 1 - A } & \multicolumn{2}{l|}{ Site 1- B } & \multicolumn{2}{l|}{ Site 2- A } & \multicolumn{2}{l|}{ Site 2- B } & \multicolumn{2}{l|}{ Site 3- A } & \multicolumn{2}{l|}{ Site 3- B } & \multicolumn{2}{l|}{ Site 3- C } \\
\hline & $\mathrm{n}$ & $\%$ & $\mathrm{n}$ & $\%$ & $\mathrm{n}$ & $\%$ & $\mathrm{n}$ & $\%$ & $\mathrm{n}$ & $\%$ & $\mathrm{n}$ & $\%$ & $\mathrm{n}$ & $\%$ \\
\hline Female & 280 & 53.5 & 405 & 65 & 1246 & 57.1 & 547 & 56 & 70 & 47.3 & 52 & 37.4 & 34 & 27 \\
\hline Male & 243 & 46.5 & 218 & 35 & 915 & 41.9 & 394 & 40.4 & 78 & 52.7 & 87 & 62.6 & 92 & 73 \\
\hline Missing & 0 & 0 & 0 & 0 & 21 & 1 & 35 & 3.6 & 0 & 0 & 0 & 0 & 0 & 0 \\
\hline Total & 523 & & 623 & & 2182 & & 976 & & 148 & & 139 & & 139 & \\
\hline
\end{tabular}

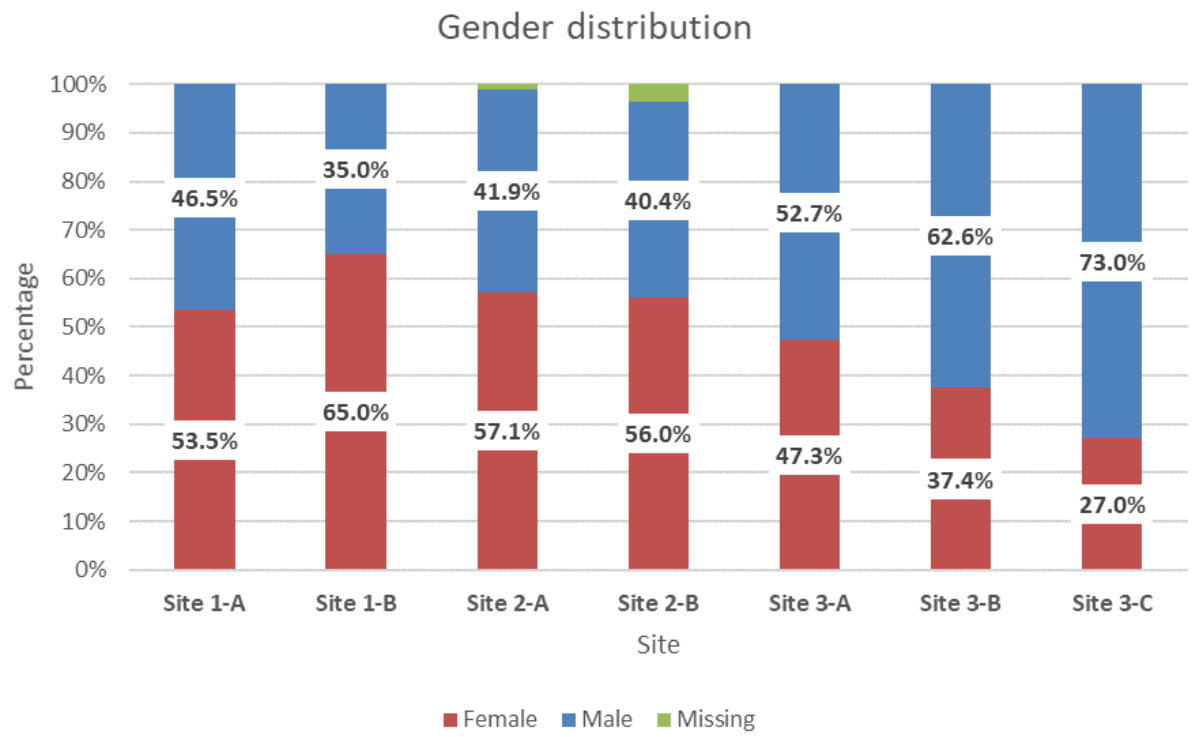

Figure 2 Gender distribution in the different studied areas

\subsubsection{Thermal sensation votes}

The users' thermal perception votes were identified through the ASHRAE 7-points scale. Almost $23 \%$ of the total respondents were feeling neutral. Percentages of $12 \%$ and $65.3 \%$ of the respondents inclined towards the cold and warm directions, respectively. The frequency distribution of thermal sensation votes for the different studied areas are shown in Table 5. 
Table 5 Distribution of thermal sensation votes at the different studied areas.

\begin{tabular}{|l|l|l|l|l|l|l|l|}
\hline Site & Cold & Cool & $\begin{array}{l}\text { Slightly } \\
\text { cool }\end{array}$ & Neutral & $\begin{array}{l}\text { Slightly } \\
\text { Warm }\end{array}$ & Warm & Hot \\
\hline $1-\mathrm{A}$ & $0.6 \%$ & $6.3 \%$ & $11.9 \%$ & $24.7 \%$ & $32.5 \%$ & $22.2 \%$ & $1.9 \%$ \\
\hline $1-\mathrm{B}$ & $2.9 \%$ & $8.5 \%$ & $15.6 \%$ & $20.4 \%$ & $20.4 \%$ & $26.2 \%$ & $6.1 \%$ \\
\hline $2-\mathrm{A}$ & $0.1 \%$ & $0.9 \%$ & $4.6 \%$ & $19.2 \%$ & $28.4 \%$ & $30.8 \%$ & $16 \%$ \\
\hline $2-\mathrm{B}$ & $0.1 \%$ & $1.64 \%$ & $7.6 \%$ & $32.34 \%$ & $27.72 \%$ & $22.28 \%$ & $8.32 \%$ \\
\hline $3-\mathrm{A}$ & $0.7 \%$ & $5.4 \%$ & $27.0 \%$ & $20.9 \%$ & $27 \%$ & $18.2 \%$ & $0.7 \%$ \\
\hline $3-\mathrm{B}$ & $0 \%$ & $0 \%$ & $2.2 \%$ & $12.9 \%$ & $25.9 \%$ & $44.6 \%$ & $14.4 \%$ \\
\hline $3-\mathrm{C}$ & $0 \%$ & $1.6 \%$ & $23.8 \%$ & $25.4 \%$ & $24.6 \%$ & $17.5 \%$ & $7.1 \%$ \\
\hline
\end{tabular}

\subsubsection{Neutral temperature}

The neutral temperature value is generally generated from the linear regression between the mean thermal sensation votes (MTSV) and the calculated PET. For precision, the respondents' MTSV is determined for each $1^{\circ} \mathrm{C}$ PET intervals. A significant correlation between the two variables was obtained as per Eq. (2) and Figure 3.

$$
\mathrm{MTSV}=0.075 \text { PET }-1.204 \quad \mathrm{R} 2=0.821, \mathrm{p}<.001
$$

The neutral temperature (PET) is then calculated by substituting MTSV=0 in Eq. (2), to be $16.1^{\circ} \mathrm{C}$. 


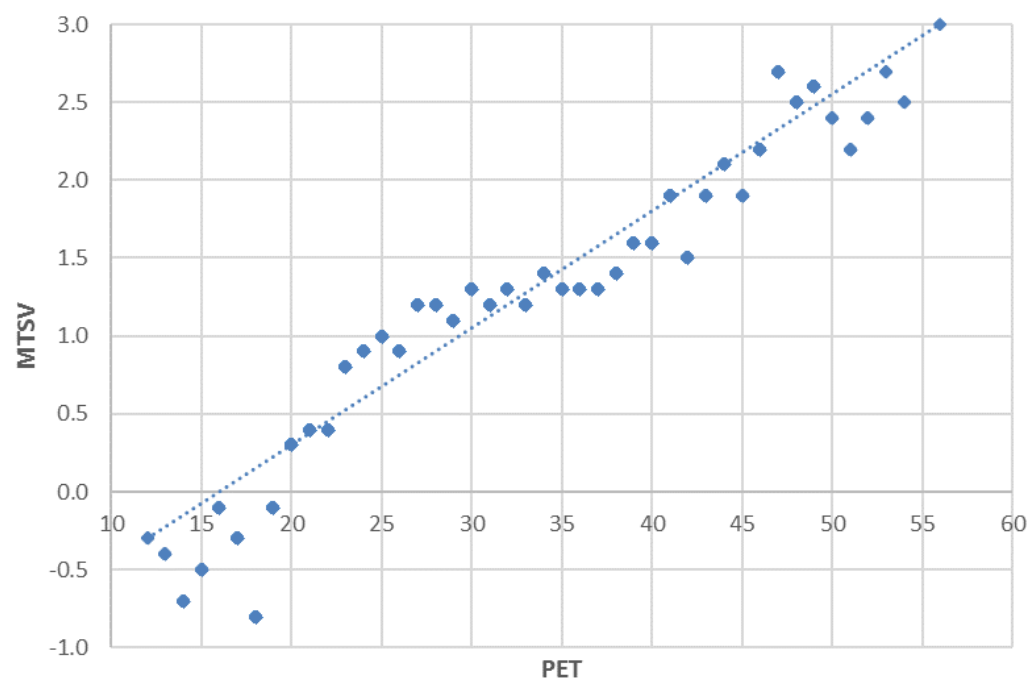

Figure 3 Linear regression between MTSV and PET

\subsubsection{Preferred temperature}

The preferred temperature value is calculated from the intersection of the modelled probit regression analysis for both cooler and warmer preferences [46]. The value of the preferred temperature obtained from the two fitted lines is $21.5^{\circ} \mathrm{C}$. The goodness fits of the probit regression model for cooler and warmer preferences are identified by statistically significant chi-square of $\left(\mathrm{X}^{2}=143.469, \mathrm{~d}(\mathrm{f})=42, \mathrm{p}<0.01\right)$ and $\left(\mathrm{X}^{2}=202.654 \mathrm{~d}(\mathrm{f})=42, \mathrm{p}<0.01\right)$ respectively (Figure 4$)$. 


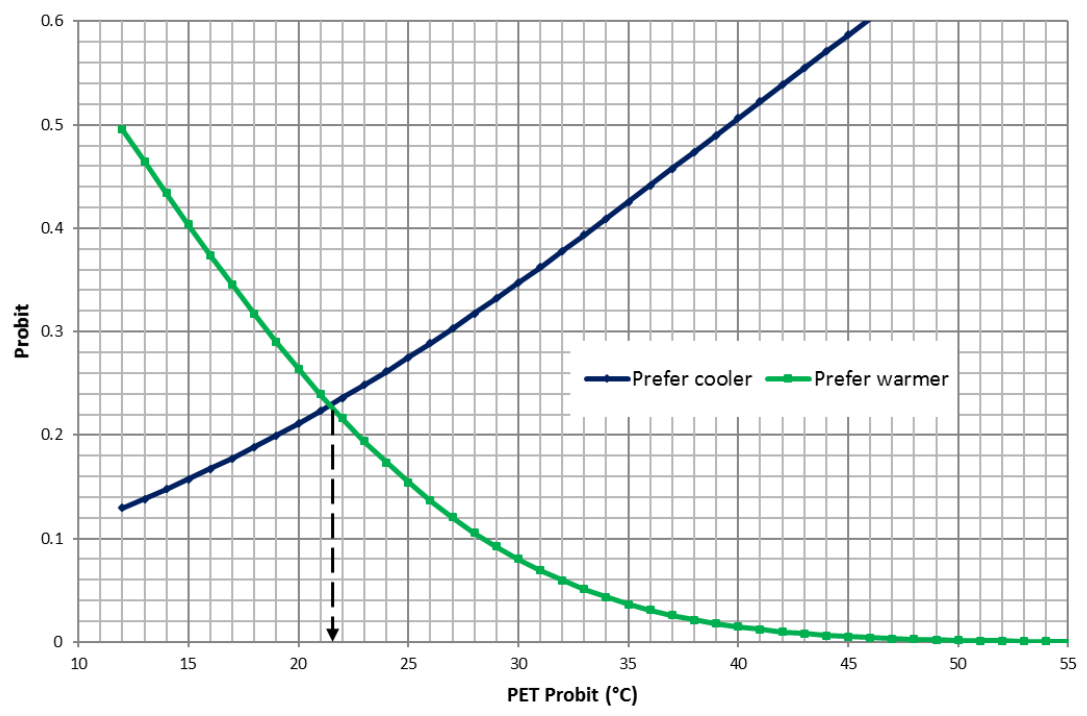

Figure 4 Probit regression model for cooler and warmer preferences

\subsubsection{Acceptable thermal range}

The acceptable thermal range (ATR) is generally identified by the line intersection $80 \%$ acceptability in the quadratic polynomial fitting the acceptability percentages against the PET index values. The acceptability rate has been calculated using various methods [34]. The first method used in this study was based on the thermal sensation scale, considering the three central points- slightly cool, neutral, slightly warm- as acceptable rates. Only the maximum acceptable rate could be retrieved from this method to be $19.8^{\circ} \mathrm{C}$ as shown in Figure 5 .

The acceptability rates were also calculated considering the thermal preference votes for the respondents. In this case, a preference of no change in the weather conditions was considered a thermal acceptable vote. This method failed to provide an ATR within the $20 \%$ acceptability threshold as shown in Figure 6.

To further investigate the ATR, both previous methods were combined to calculate the thermal acceptability rates. An acceptable vote was to have a thermal sensation votes varying between 
slightly cool to slightly warm as well as having a preference vote of no change in the weather conditions. In this case, an acceptable thermal range varying between $3.4^{\circ} \mathrm{C}$ and $28.2^{\circ} \mathrm{C}$ was obtained as shown in Figure 7. For more precision, a percentage of $88 \%$ were selected to define the ATR. It was found to vary between $11.3^{\circ} \mathrm{C}$ and $20.3^{\circ} \mathrm{C}$. 


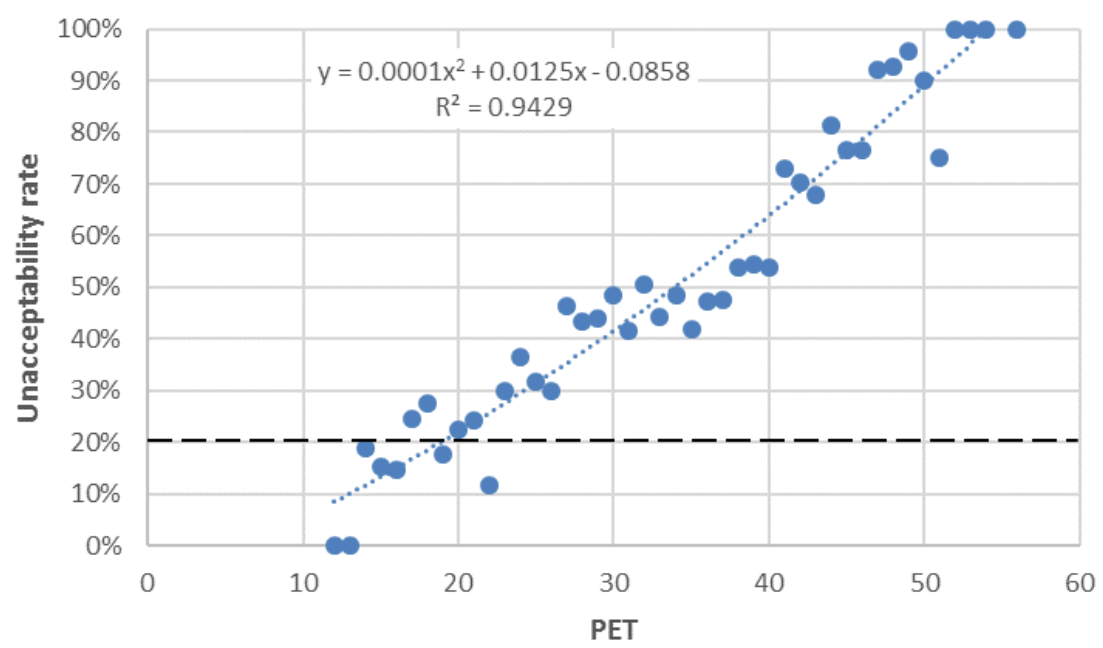

Figure 5 Determination of acceptable thermal range using thermal sensation votes

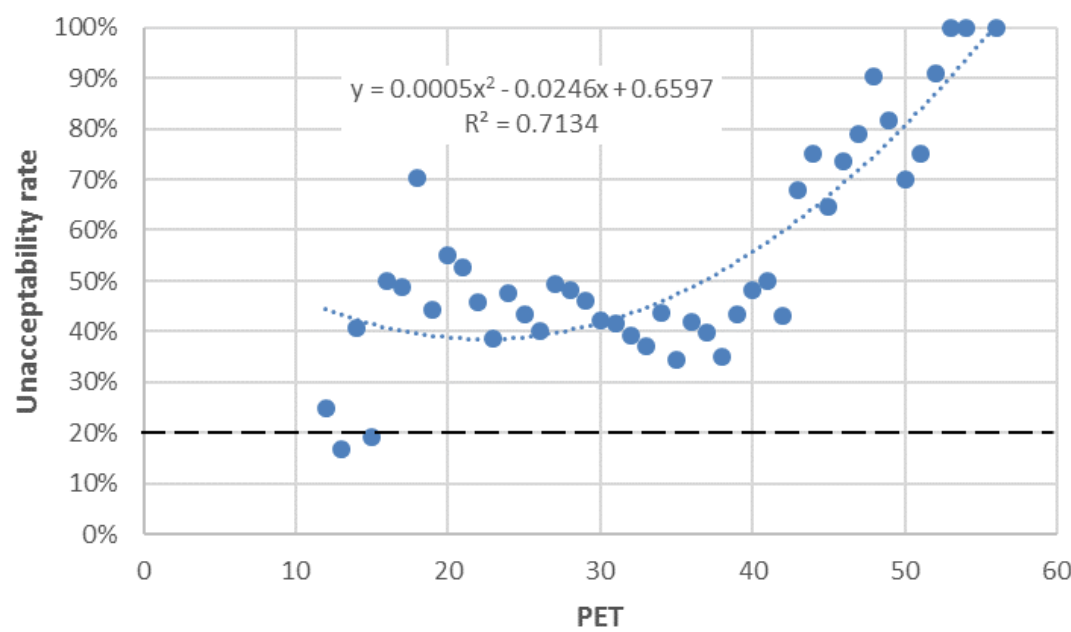

Figure 6 Determination of acceptable thermal range using thermal preferences

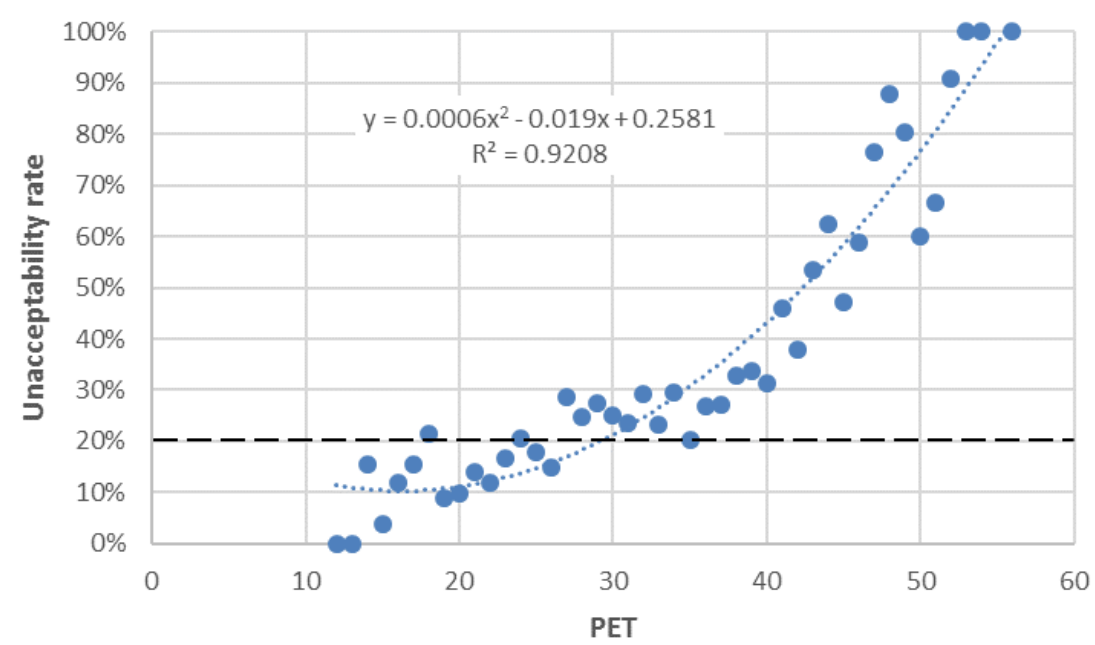

Figure 7 Determination of acceptable thermal range using thermal sensation votes and preferences 


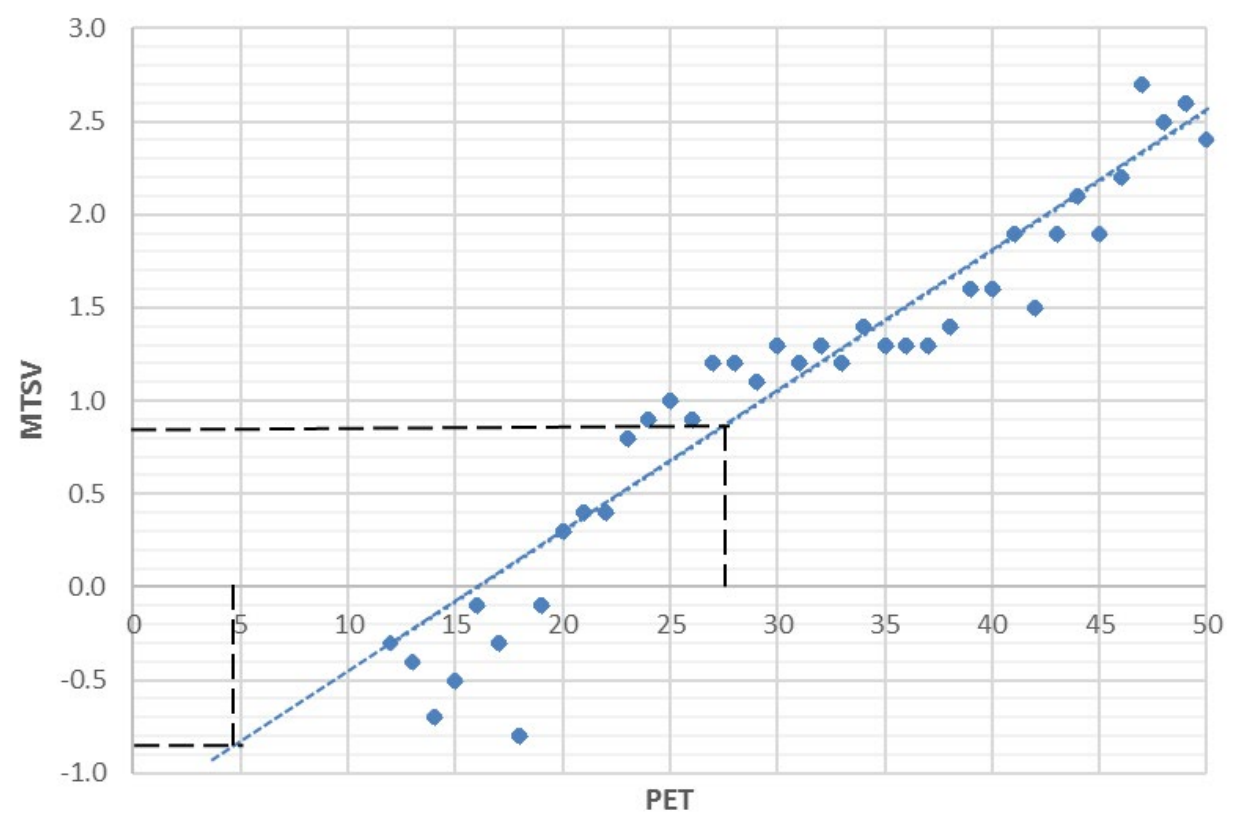

Figure 8 Determination of acceptable thermal range using linear regression between MTSV and PET

This benchmark has been also calculated by substituting MTSV $= \pm 0.85$ in Eq. (2) being equivalent to the $80 \%$ thermal acceptability rate [47]. The ATR varied using this method between $4.7^{\circ} \mathrm{C}$ and $27.4^{\circ} \mathrm{C}$ as shown in Figure 8.

\subsubsection{Thermal comfort ranges}

The classification for the thermal ranges for Melbourne during summer was calculated using the thermal comfort acceptability range as shown in Table 6. As previously mentioned, the three central categories in the thermal sensation scale are assumed to be equivalent to thermal acceptability. According to this assumption, the thermal sensation votes of slightly cool and slightly warm represent the minimum and maximum values of the thermal acceptability range. 
Table 6 Thermal response categories

\begin{tabular}{|l|lllllll|}
\hline Scale & Cold & Cool & $\begin{array}{c}\text { Slightly } \\
\text { cool }\end{array}$ & Neutral & Slightly & Warm & Hot \\
& & & & Warm & & \\
\hline Value & 2 & 6.5 & 11 & 15.5 & 20 & 24.5 & 29 \\
\hline
\end{tabular}

\section{Discussions}

The outdoor thermal benchmark differs when it is assessed by neutral temperature, preferred temperature, or acceptable temperature range. The difference between these indicators is conceptualized by Spagnolo and de Dear [48]. They described the human thermal environment 'as a set of concentric 'zones' with thermal preference at its centre, flanked by a wider band of thermally comfortable conditions, which in turn may be ranked by wider bands of acceptable thermal conditions' (p. 722). The comfortable temperature range can be a confusing term as it is sometimes assumed as the neutral temperature range or acceptable thermal range (ATR) [33]. It would be better to use the neutral temperature range and ATR as their definitions are more precise. In our study, the neutral PET range $\left(9.4^{\circ} \mathrm{C}-22.7^{\circ} \mathrm{C}\right)$ is wider than the ATR $\left(11.3^{\circ} \mathrm{C}-20.3^{\circ} \mathrm{C}\right)$ (Figure 9). This result demonstrates that different analysis techniques can affect the values obtained for different thermal benchmarks, which has been highlighted in previous studies [30, 33, 34, 49-51]. Unfortunately, there has been no standardised approaches for determining outdoor thermal benchmarks, which make an international comparison of past study results difficult [49]. The following sections evaluate different ways to determine thermal benchmarks and provide recommendations for improving current ways to assess outdoor thermal benchmarks. 


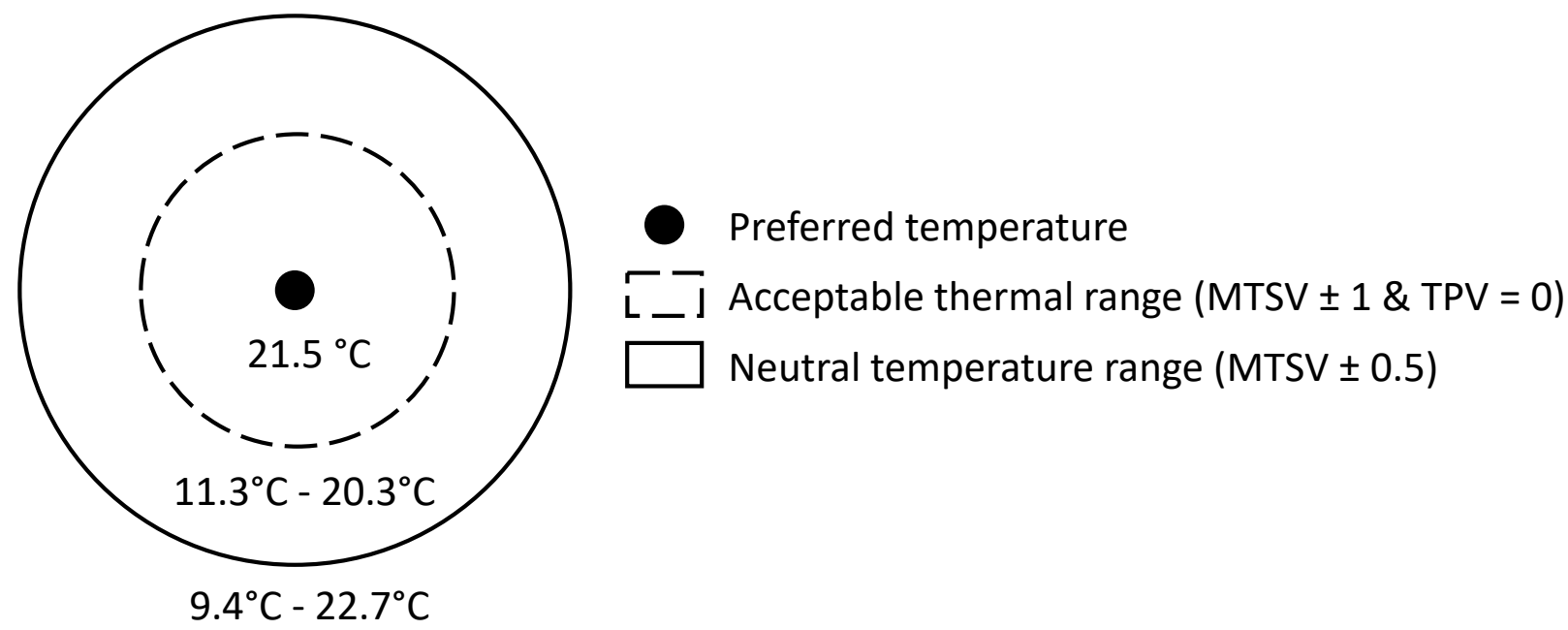

Figure 9 Concentric zones regarding the human thermal environment in Melbourne (modified from Spagnolo and de Dear [48]). The MTSV and TPV refer to the mean thermal sensation vote and thermal preference vote.

\subsection{Neutral PET and neutral PET range}

The neutral PET in our Melbourne study is $16.1{ }^{\circ} \mathrm{C}$ (Figure 3), which is lower than other Melbourne sites in summer, such as public squares, university campuses $\left(20^{\circ} \mathrm{C}\right)[21]$, and education precinct $\left(20.47^{\circ} \mathrm{C}\right)$ [52]. Since this study involves multiple sites in Melbourne, the lower neutral PET in our study can be skewed by the lower PET values reported in botanic gardens (13.9 ${ }^{\circ} \mathrm{C}$ for Melbourne Gardens and $19.2{ }^{\circ} \mathrm{C}$ for Cranbourne Gardens) [20]. Our findings agree with Heng and Chow [53], who discovered that neutral PET in urban parks in Singapore $\left(26.6^{\circ} \mathrm{C}\right)$ is lower than urban areas in the same city $\left(28.1^{\circ} \mathrm{C}\right)$ [54]. Our results demonstrate that neutral PET depends on the context and characteristics of study sites.

There are different ways to determine neutral PET. Many studies have used linear regression between PET and mean thermal sensation vote (MTSV), and substituted MTSV $=0$ to obtain neutral PET. Other studies have suggested using weighted linear regression to retain the sample size of each PET bin $[47,49,55]$. Although the linear regression method is simple to perform, it 
has been criticized for several reasons. Firstly, sometimes the linear regression line does not touch the $\mathrm{x}$-axis (MTSV=0), so the neutral temperature cannot be determined. Secondly, the TSV is ordinal data. As linear regression is appropriate for continuous scales, treating TSV as continuous data might be inappropriate [33]. Thirdly, both early studies in the 1970s [56-58] and recent studies $[26,59]$ have discovered that the TSV scale is not equidistant. For example, the distance of the verbal anchor between neutral and slightly warm is narrower than warm and hot. This result means that statistics relevant to ordinal scales could be used instead of those applying for a continuous scale.

Another issue is that the relationship between temperature and TSV can be non-linear [59], in which quadratic regression might be used. Alternative approaches have been proposed, such as using probit and logistic regression. Ordinal logistic regression has been used to obtain neutral PET, in which the probability of TSV $=0$ is higher than other TSV categories [60]. Moreover, neutral PET can be determined by finding the probability that TSV $=0$ is the highest [33]. Neutral temperature indicates thermal neutrality, but the middle point between weak and strong on a Likert scale does not necessarily refer to neutral or comfortable [61]. Furthermore, thermal neutrality is often not the same as thermal comfort.

Conventionally, the neutral temperature range (MTSV \pm 1 or MTSV \pm 0.5 ) is considered to reveal thermally comfortable conditions. This idea stems from early indoor thermal comfort studies [58, 62-64] and is later applied to outdoor comfort studies [65, 66]. The neutral temperature range assumes that neutrality (feeling neither warm nor cool) is the optimal thermal sensation. However, neutrality is often not the desired thermal sensation, which has been highlighted by Fountain et al. [67], Humphreys and Hancock [68] and Shahzad et al. [69]. In a Hong Kong study, the percentage 
of TSV $=0$ was smaller than the percentage of people who reported comfortable [70]. Thermal comfort can also differ depending on environmental parameters and context factors, in which people could feel comfortably warm or comfortably cool. For example, the comfortable temperature for beach tourists [71] is likely to differ from people passing by an urban square or office workers. This discrepancy indicates the effect of thermal expectation on thermal perception, which relates to preferred temperature and PET.

\subsection{Preferred PET}

Probit analysis is the usual method to determine preferred PET. In the probit analysis, the preferred PET is where the 'prefer warmer' and 'prefer cooler' curve intersects. The preferred PET in our Melbourne study is $21.5{ }^{\circ} \mathrm{C}$ (Figure 4), which differs from urban squares $\left(23.2{ }^{\circ} \mathrm{C}\right)$ [21] and education precinct in Melbourne during summer $\left(24.6^{\circ} \mathrm{C}\right.$ using linear regression and $15{ }^{\circ} \mathrm{C}$ using probit analysis) [9]. In some cases, the preferred PET is predicted by extending the probit relationship between the 'prefer cooler' and 'prefer warmer' curves. This approach would increase the uncertainty of preferred PET as people do not encounter those lower PET situations [53]. More of a caveat should be placed on preferred PET obtained this way. There are different ways to deal with the 'no change' preference vote. Some studies did not specify how they handled this issue $[72,73]$. In contrast, other studies have split the 'no change' vote evenly into the 'prefer warmer' and 'prefer cooler' group $[48,74]$. Cheung and Jim [33] have also suggested that using the highest probability of TPV $=0$ as the preferred temperature would be appropriate.

Thermal preference demonstrates a psychological adaptation that involves thermal experience and expectation $[75,76]$. The desired thermal sensation can change at different times of the day [69] 
and it depends on the current sensation [68]. Past studies found that some people characteristically prefer to feel warmer, which is owing to personality traits [77], gender [78, 79], and body mass index $[78,80]$. If there are adaptive opportunities (e.g. clothing, seeking shade), the desired sensation could be similar to the current sensation [68]. Thermal preference also depends on both indoor and outdoor climatic conditions. People are shown to prefer sensation below neutrality if it is warm outdoor and cool indoor, whereas they prefer sensation above neutrality if it is cool outdoor and warm indoor. These results reveal the semantic offset on the thermal sensation scale. Moreover, alliesthesia (changed sensation) $[81,82]$ is used to explain why sensation outside the thermal neutral range can be considered as preferable, especially under transient conditions. For example, if a person transits from a static warm condition to a cool dynamic condition, a cool sensation might be preferable [83]. As neutrality is often not the preferred sensation [68], preferred PET has been shown to differ from neutral PET in past studies [21, 76, 84], which is known as the semantic discrepancy [85].

\subsection{Discrepancy between neutral and preferred PET}

In this study, Melbourne people's preferred PET $\left(21.5^{\circ} \mathrm{C}\right)$ is higher than neutral PET $\left(16.1^{\circ} \mathrm{C}\right)$, which is influenced by the context of survey sites [34] and expectation [9, 84]. As our study encompasses multiple landscapes, the higher preferred PET could be related to the characteristics of survey sites. Similar findings were obtained in another Melbourne study during summer [9]. The 'semantic artefact hypothesis' [85] has been proposed to explain the difference between neutral and preferred temperature and PET. This hypothesis suggests that the preferred thermal state is slightly warm in a cold climate and slightly cool in a warm climate. This effect is also more substantial in a warm climate but less apparent in a cool climate. In summer, the preferred PET is 
usually lower than neutral PET [74]. However, this is not the case in our study and our results do not seem to support the semantic artefact hypothesis. Another approach has been proposed to discern the difference between the percentage of 'neutral' vote and 'no change' vote, which results in the tolerance rate, showing the degree of tolerance of a population [72]. Apart from climatic conditions (indoor or outdoor), the scaling techniques in survey questions (e.g. language and presentation of questions) is another possible reason for the discrepancy between neutral and preferred temperature [86]. Different groups of respondents could interpret the scale differently regarding the distances of the verbal anchors and relationships between various scales [26]. Overall, contextual factors, such as climate, season and language, could affect people's interpretation of the thermal sensation and preference scales [26], potentially leading to the divergence in preferred and neutral PET.

\subsection{Acceptable thermal range (ATR)}

Using different techniques could result in a wide range of acceptable thermal range (ATR) (Figure 5 to Figure 8). ASHRAE [42] states that a thermal environment is deemed acceptable if more than $80 \%$ (typical) or $90 \%$ of people find it acceptable (a higher standard). There are both direct and indirect methods to assess thermal acceptability. Past studies have recommended using the direct method - using the 2-point acceptability question (e.g. generally acceptable and generally unacceptable [87]. However, the Melbourne botanic garden studies did not use personal acceptability scales. To facilitate comparing our three survey datasets, we used different indirect methods to evaluate ATR, which is generated from quadratic regression between acceptability levels and PET. Using TSV \pm 1 to determine ATR is not suitable as the lower range of ATR cannot be determined (Figure 5). Several studies also questioned TSV \pm 1 to represent acceptable thermal 
conditions $[65,88]$. Using TSV \pm 0.85 to indicate that thermal acceptability has also been used [47]. This TSV range assumes $80 \%$ acceptability, according to ISO 7730 [44]. However, this approach might not be applicable, as ISO 7730 is intended for indoor use [33]. By using only TPV $=0$, the ATR also cannot be determined as no data points intersect the $20 \%$ unacceptability rate (Figure 6). Alternatively, a TPV \pm 0.125 has been used to indicate thermal acceptability [89]. We suggest that a more suitable indirect method is combining votes of TSV \pm 1 and TPV $=0$ [34], which results in a more reasonable ATR using an $88 \%$ acceptability level (Figure 7). Acceptability levels other than $80 \%$ and $90 \%$ have been reported in other studies (e.g. 88\% [90] and 70\% [91, 92]), in order to minimize data range and to account for a greater variation of outdoor thermal conditions.

Most ATR reported in the literature is the transient ATR (right here, right now response). The range of transient ATR can be broad (e.g. $>40{ }^{\circ} \mathrm{C}$ in some cases [93]). This wide ATR range is due to several reasons. Firstly, microclimatic conditions, study site characteristics, and analytical methods can affect ATR [21,33,34]. Secondly, the transient thermal condition could overestimate thermal comfort (including thermal acceptability). Some people only need to stay outdoor for a brief moment, and they have the freedom to leave that place if the outdoor conditions become unbearable [91]. In extreme heat conditions, self-selection bias might occur as people who cannot accept the outdoor conditions would likely stay indoors [94]. Thirdly, exposure time could affect ATR. People take time to develop physiological strain when they transit from indoor to outdoor. At least 30 minutes are required for people to reach thermal equilibrium in hot conditions [95]. Some people might not reach this thermal equilibrium if they only stay outdoor for a short time. 
To address the issues of transient ATR, Cheung and Jim [91] recommended using a 1-hour ATR, which reveals whether people find it acceptable to stay in an outdoor location for one hour. The 1hour ATR resulted in a more reasonable and narrower ATR than transient ATR. Overall, the ATR is considered unsuitable if the range is too broad (covering temperature conditions not encountered during the survey period). Judging a reasonable ATR can be subjective, as it depends on urban planning guidelines and the purpose of using the outdoor space, which can vary between climates, contexts, and activities.

\subsection{Limitations and future directions}

This study covers multiple sites with different landscape features, representing a reliable outdoor thermal benchmark for Melbourne during summer. Despite our relatively large sample size, we acknowledge several limitations of our study. Firstly, our three case studies used different questions to assess thermal acceptability in outdoor spaces. Conventionally, ATR is determined by the $80 \%$ acceptability in a quadratic polynomial regression between the acceptability percentages and the PET. This approach requires the survey to include a question of thermal acceptability (i.e. thermally acceptable or unacceptable). Since study 2 (botanic garden) does not have the thermal acceptability question, we choose other indirect methods to determine ATR [34]. One of such methods determines an acceptable vote as people reporting a thermal sensation vote (7-point scale) between slightly cool to slightly warm and a thermal preference vote (3-point scale) of no change in the weather conditions. Accordingly, this has limited the analytical capability to assess ATR benchmark using all the available techniques; this limitation makes standardization and comparison of past studies difficult [29, 30, 49]. A more standardised approach is necessary. The ATR has been advocated as a better thermal benchmark than neutral temperature and neutral 
temperature range. However, it is worthwhile to explore combinations of different scales and evaluates the correlation between different scales and the underlying dimensions using principal component analysis or hierarchical clustering [59].

Secondly, our study used the 3-point thermal preference vote, which could not indicate how much warmer or cooler people want. A double-enquiry method has been proposed to address this issue by asking people how they would like to feel (using the same TSV scale), following the question about their current TSV. Several indoor studies have adopted this approach [96-98], but limited outdoor studies have employed this method.

Thirdly, the outdoor thermal benchmark is affected by multiple factors apart from climatic variables. We acknowledge that thermal benchmarks likely differ in various urban forms and climates $[31,32,99]$. Previous studies reveal that the summer neutral PET range in Melbourne is different for Federation Square and university campus $\left(17^{\circ} \mathrm{C}-22.9^{\circ} \mathrm{C}\right)[21]$, education precincts $\left(16.5^{\circ} \mathrm{C}-24.5^{\circ} \mathrm{C}\right)[9,52]$ and botanic gardens $\left(6.8^{\circ} \mathrm{C}-27.7^{\circ} \mathrm{C}\right)[20,39]$. As this study focuses on different techniques to determine thermal benchmarks, it is beyond the scope of this study to compare thermal benchmarks in these urban forms. Moreover, the purpose of the visit could affect thermal acceptability and tolerance, depending on respondents' perceived control. For instance, a person who chooses to stay in one location will likely have higher acceptability of the thermal environment than a passer-by [91]. Moreover, age, exercise history, lifestyle preference (e.g. nature vs. no preference), and residence time were shown to affect transient acceptability [91] and other thermal comfort indicators. The relationship between these variables and outdoor thermal comfort can be examined using path analysis [100] and a non-linear model with Box-Cox transformation [80]. Other non-thermal factors such as glare, acoustics, air quality, and odour were 
also shown to have cross-modal effects on thermal comfort [91, 101]. It requires further outdoor studies to verify the nature of interactions between different perceived outdoor environmental quality factors (e.g. [102]) and whether it affects the outdoor thermal benchmark.

Our discussion so far has been limited to the traditional thermal comfort scales recommended by ISO 10551 [87]. The term 'warm' on the TSV scale can refer to comfortably warm or uncomfortably hot conditions depending on the context of the study $[61,67,71]$. This situation raises the question of the linguistic ambiguity of the TSV scale. Recent studies have suggested using multi-dimensional scales to assess thermal comfort instead of unidimensional thermal sensation scale [26, 59, 88]. Liu et al. [88] presented a paradigm shift from the ISO 10551 framework by introducing the concept of outdoor thermal affect (OTA), which refers to the 'feeling or emotion elicited by outdoor thermal stimuli'. The OTA includes a six-dimensional semantic space that includes the descriptive dimension (temperature, humidity, wind, solar radiation) and the affect dimensions (thermal pleasure and thermal intensity). Moreover, Liu et al. [88] advocated using a range of thermal affect words to express thermal comfort rather than the traditional 7-point scales. The use of these thermal affect words would require further validation in different climatic contexts and language groups.

The OTA suggests a possible influence of emotion on thermal perception. Further studies can examine this relationship in surveys using the Positive and Negative Affects Schedule (PANAS) [103] (e.g. applied by Peng et al. [80]), or Profile of Mood States (POMS) [104] (e.g. applied by Lan and Lian [105]). Moreover, Schweiker et al. [59] derived sensory-discriminative, affectmotivational, and cognitive questions from pain research to assess thermal comfort. To capture a richer expression of thermal comfort and emotions, researchers could adopt thematic analysis from 
semi-structured interviews [106] and 'think-aloud methods' (verbally expressing thoughts while completing tasks) [107]. Overall, it requires more field studies to validate the use of these questions and approaches in outdoor thermal comfort research.

\section{Conclusion}

This study aimed to determine the summer thermal comfort requirements of people visiting outdoor spaces in Melbourne building on 4,717 survey data. The collective impact of six thermal comfort factors (air temperature, wind velocity, relative humidity, clothing insulation, metabolic activity), measured in three studies, was used to create a thermal benchmark for Melbourne outdoor spaces. The benchmarking revealed that the value of summer (PET) acceptable thermal range is between $11.3^{\circ} \mathrm{C}$ and $20.3^{\circ} \mathrm{C}$, the preferred temperature is $21.5^{\circ} \mathrm{C}$, and the neutral temperature is $16.1^{\circ} \mathrm{C}$.

The benchmark builds a pathway to creating sustainable and livable outdoor spaces in Melbourne and other places with comparable microclimate conditions. As indicated earlier, the results of this study would aid policymakers in Melbourne who are in the quest of improving the liveability conditions of the city. Hence, urban design, planning and policy development activities can be evaluated and implemented against this benchmark. The study also contributes to the thermal comfort body of knowledge by demonstrating how the lack of standardised benchmarking approach can make it difficult to compare past study results. This difficulty arises from various scales used in survey questions and different analytical techniques to obtain the outdoor thermal benchmarks. To overcome this issue, we advocate a standardised approach for formulating survey questions (e.g., ISO 10551) and using similar analysis techniques. The results of the study also emphasised on the conceptual differences between thermal responses used in comfort studies. 


\section{Acknowledgement}

The three case studies were based on $\mathrm{PhD}$ research projects that were funded by Deakin University, RMIT University and, and Monash University, Australia. The case study 2 was also supported by the National Natural Science Foundation of China (No 41905005, No. 41875015, No 51811530017) and the Natural Science Foundation of Guangdong Province, China (No. 2018A030310307, No. 2018B030311068).

\section{References}

[1] The Economist Intelligence Unit, The Global Liveability Index 2019, The Economist 2019.

[2] M. Kashef, Urban livability across disciplinary and professional boundaries, Frontiers of Architectural Research 5(2) (2016) 239-253. doi:https://doi.org/10.1016/j.foar.2016.03.003

[3] ABS, National, state and territory population, Statistics about the population and components of change (births, deaths, migration) for Australia and its states and territories, Australian Bureau of Statistics Canberra, Australia, 2019.

[4] P. Chhetri, J.H. Han, S. Chandra, J. Corcoran, Mapping urban residential density patterns: Compact city model in Melbourne, Australia, City, Culture and Society 4(2) (2013) 77-85

[5] A. Dellios, 'It was just you and your child': Single migrant mothers, generational storytelling and Australia's migrant heritage, Memory Studies 13(4) (2020) 586-600

[6] J. Lesh, Social value and the conservation of urban heritage places in Australia, Historic Environment 31(1) (2019) 42-62

[7] T.J. Entwisle, C. Cole, P. Symes, Adapting the botanical landscape of Melbourne Gardens (Royal Botanic Gardens Victoria) in response to climate change, Plant diversity 39(6) (2017) 338347

[8] N. Belford, International students from Melbourne describing their cross-cultural transitions experiences: Culture shock, social interaction, and friendship development, Journal of International Students 7(3) (2017) 499-521

[9] S. Shooshtarian, P. Rajagopalan, Study of thermal satisfaction in an Australian educational $\begin{array}{llllll}\text { precinct, } & \text { Building } & 123 & \text { (2017) }\end{array}$ doi:https://doi.org/10.1016/j.buildenv.2017.07.002 
[10] The Department of Education, 2019 International student data summary The Department of Education, Canberra, Australia, 2019.

[11] M. Nieuwenhuijsen, Seven steps Melbourne can take to regain its 'liveable city' crown, The Conversation, The Conversation, Online, 2019.

[12] Centre for Urban Research, Creating liveable cities in Australia: A scorecard and priority recommendations for Melbourne, Centre for Urban Research, RMIT University, Melbourne, Australia 2018.

[13] The State Government of Victoria, Plan Melbourne 2017-2050, Five Year Implementation Plan, The State of Victoria Department of Environment, Land, Water and Planning 2017, Melbourne, 2017.

[14] The State Government of Victoria, 20-Minute Neighbourhoods Creating a more liveable Melbourne, 2019.

[15] A. Auliciems, Advances in Bioclimatology, Springer, Brisbane, Australia 1997.

[16] M. Rutty, D. Scott, Comparison of climate preferences for domestic and international beach holidays: A case study of Canadian travelers, Atmosphere 7(2) (2016) 30

[17] S. Shooshtarian, Priyadarsini Rajagopalan, R. Wakefield., Effect of seasonal changes on usage patterns and behaviours in educational precinct in Melbourne, Urban Climate 26 (2018) 133148. doi:https://doi.org/10.1016/j.uclim.2018.08.013

[18] CSIRO, Technical report: Climate Change in Australia, Australian Department of Environment, 2015.

[19] S. Shooshtarian, P. Rajagopalan, A. Sagoo, A comprehensive review of thermal adaptive strategies in outdoor spaces, Sustainable Cities and Society 41 (2018) 647-665. doi:https://doi.org/10.1016/j.scs.2018.06.005

[20] S. Shooshtarian, C.K.C. Lam, I. Kenawy, Outdoor thermal comfort assessment: A review on thermal comfort research in Australia, Building and Environment 177 (2020) 106917. doi:https://doi.org/10.1016/j.buildenv.2020.106917

[21] I. Kenawy, H. Elkadi, The outdoor thermal benchmarks in Melbourne urban climate, Sustainable Cities and Society 43 (2018) 587-600. doi:https://doi.org/10.1016/j.scs.2018.09.004

[22] C.K.C. Lam, A.J.E. Gallant, N.J. Tapper, Perceptions of thermal comfort in heatwave and non-heatwave conditions in Melbourne, Australia, Urban Climate 23 (2018) 204-218. doi:http://dx.doi.org/10.1016/j.uclim.2016.08.006 
[23] C.K.C. Lam, M. Loughnan, N. Tapper, Visitors' perception of thermal comfort during extreme heat events at the Royal Botanic Garden Melbourne, International Journal of Biometeorology 62(1) (2018) 97-112. doi:10.1007/s00484-015-1125-4

[24] R.J. De Dear, A global database of thermal comfort field experiments, ASHRAE transactions 104 (1998) 1141

[25] V.F. Ličina, T. Cheung, H. Zhang, R. De Dear, T. Parkinson, E. Arens, C. Chun, S. Schiavon, M. Luo, G. Brager, Development of the ASHRAE global thermal comfort database II, Building and Environment 142 (2018) 502-512

[26] M. Schweiker, M. André, F. Al-Atrash, H. Al-Khatri, R.R. Alprianti, H. Alsaad, R. Amin, E. Ampatzi, A.Y. Arsano, E. Azar, B. Bannazadeh, A. Batagarawa, S. Becker, C. Buonocore, B. Cao, J.-H. Choi, C. Chun, H. Daanen, S.A. Damiati, L. Daniel, R. De Vecchi, S. Dhaka, S. DomínguezAmarillo, E. Dudkiewicz, L.P. Edappilly, J. Fernández-Agüera, M. Folkerts, A. Frijns, G. Gaona, V. Garg, S. Gauthier, S.G. Jabbari, D. Harimi, R.T. Hellwig, G.M. Huebner, Q. Jin, M. Jowkar, J. Kim, N. King, B. Kingma, M.D. Koerniawan, J. Kolarik, S. Kumar, A. Kwok, R. Lamberts, M. Laska, M.C.J. Lee, Y. Lee, V. Lindermayr, M. Mahaki, U. Marcel-Okafor, L. Marín-Restrepo, A. Marquardsen, F. Martellotta, J. Mathur, I. Mino-Rodriguez, A. Montazami, D. Mou, B. Moujalled, M. Nakajima, E. Ng, M. Okafor, M. Olweny, W. Ouyang, A.L. Papst de Abreu, A. Pérez-Fargallo, I. Rajapaksha, G. Ramos, S. Rashid, C.F. Reinhart, M.I. Rivera, M. Salmanzadeh, K. SchakibEkbatan, S. Schiavon, S. Shooshtarian, M. Shukuya, V. Soebarto, S. Suhendri, M. Tahsildoost, F. Tartarini, D. Teli, P. Tewari, S. Thapa, M. Trebilcock, J. Trojan, R.B. Tukur, C. Voelker, Y. Yam, L. Yang, G. Zapata-Lancaster, Y. Zhai, Y. Zhu, Z. Zomorodian, Evaluating assumptions of scales for subjective assessment of thermal environments - Do laypersons perceive them the way, we researchers believe?, Energy and Buildings $211 \quad$ (2020) 109761. doi:https://doi.org/10.1016/j.enbuild.2020.109761

[27] M. Schweiker, A. Abdul-Zahra, M. André, F. Al-Atrash, H. Al-Khatri, R.R. Alprianti, H. Alsaad, R. Amin, E. Ampatzi, A.Y. Arsano, M. Azadeh, E. Azar, B. Bahareh, A. Batagarawa, S. Becker, C. Buonocore, B. Cao, J.-H. Choi, C. Chun, H. Daanen, S.A. Damiati, L. Daniel, R.D. Vecchi, S. Dhaka, S. Domínguez-Amarillo, E. Dudkiewicz, L.P. Edappilly, J. Fernández-Agüera, M. Folkerts, A. Frijns, G. Gaona, V. Garg, S. Gauthier, S.G. Jabbari, D. Harimi, R.T. Hellwig, G.M. Huebner, Q. Jin, M. Jowkar, R. Kania, J. Kim, N. King, B. Kingma, M.D. Koerniawan, J. Kolarik, S. Kumar, A. Kwok, R. Lamberts, M. Laska, M.C.J. Lee, Y. Lee, V. Lindermayr, M. Mahaki, U. Marcel-Okafor, L. Marín-Restrepo, A. Marquardsen, F. Martellotta, J. Mathur, G. McGill, I. Mino-Rodriguez, D. Mou, B. Moujalled, M. Nakajima, E. Ng, M. Okafor, M. Olweny, W. Ouyang, A.L. Papst de Abreu, A. Pérez-Fargallo, I. Rajapaksha, G. Ramos, S. Rashid, C.F. Reinhart, M.I. Rivera, M. Salmanzadeh, K. Schakib-Ekbatan, S. Schiavon, S. Shooshtarian, M. Shukuya, V. Soebarto, Suhendri, M. Tahsildoost, F. Tartarini, D. Teli, P. Tewari, S. Thapa, M. Trebilcock, J. Trojan, R.B. Tukur, C. Voelker, Y. Yam, L. Yang, G. Zapata-Lancaster, Y. Zhai, Y. Zhu, Z.S. Zomorodian, The Scales Project, a cross-national dataset on the interpretation of thermal perception scales, Scientific Data 6(1) (2019) 289. doi:10.1038/s41597-019-0272-6 
[28] M. Nikolopoulou, S. Lykoudis, Thermal comfort in outdoor urban spaces: Analysis across different European countries, Building and Environment 41(11) (2006) 1455-1470. doi:http://dx.doi.org/10.1016/j.buildenv.2005.05.031

[29] K.K.L. Lau, E. Krüger, Establishing a global database for outdoor thermal comfort survey: A pilot study of standardisation of methodology, The 11th Windsor Conference: Resilient Comfort, Cumberland Lodge, Windsor, 2020, pp. 1073-1085.

[30] K. Pantavou, S. Lykoudis, M. Nikolopoulou, I.X. Tsiros, Thermal sensation and climate: a comparison of UTCI and PET thresholds in different climates, International Journal of Biometeorology 62(9) (2018) 1695-1708. doi:10.1007/s00484-018-1569-4

[31] F. Salata, I. Golasi, N. Treiani, R. Plos, A. de Lieto Vollaro, On the outdoor thermal perception and comfort of a Mediterranean subject across other Koppen-Geiger's climate zones, Environmental research 167 (2018) 115-128

[32] O. Potchter, P. Cohen, T.-P. Lin, A. Matzarakis, Outdoor human thermal perception in various climates: A comprehensive review of approaches, methods and quantification, Science of the Total Environment 631 (2018) 390-406

[33] P.K. Cheung, C.Y. Jim, Determination and application of outdoor thermal benchmarks, $\begin{array}{lllll}\text { Building and } & \text { Environment } 333-350 .\end{array}$ doi:https://doi.org/10.1016/j.buildenv.2017.07.008

[34] S. Shooshtarian, I. Ridley, Determination of acceptable thermal range in outdoor built environments by various methods, Smart and Sustainable Built Environment 5(4) (2016) 352-371

[35] K.K.-L. Lau, S.C. Chung, C. Ren, Outdoor thermal comfort in different urban settings of subtropical high-density cities: An approach of adopting local climate zone (LCZ) classification, $\begin{array}{lllll}\text { Building and } & \text { 227-238. }\end{array}$ doi:https://doi.org/10.1016/j.buildenv.2019.03.005

[36] L. Liu, Y. Lin, Y. Xiao, P. Xue, L. Shi, X. Chen, J. Liu, Quantitative effects of urban spatial characteristics on outdoor thermal comfort based on the LCZ scheme, Building and Environment 143 (2018) 443-460. doi:https://doi.org/10.1016/j.buildenv.2018.07.019

[37] S. Shooshtarian, Evaluation of Microclimates and Thermal Perceptions of Educational Precincts School of Property, Construction and Project Management, RMIT University, Melbourne, Australia, 2017.

[38] I.M.E.D. Kenawy, Cultural diversity and thermal comfort in outdoor public places. School of Architecture and Built Environment, Deakin University Geelong, Australia, 2013.

[39] C.K.C. Lam, Landscape variability of Melbourne's botanic gardens and visitor thermal comfort. Monash University, Melbourne, 2017. 
[40] E. Johansson, S. Thorsson, R. Emmanuel, E. Krüger, Instruments and methods in outdoor thermal comfort studies - The need for standardization, Urban Climate 10, Part 2 (2014) 346-366. doi:http://dx.doi.org/10.1016/j.uclim.2013.12.002

[41] V.L. Castaldo, I. Pigliautile, F. Rosso, F. Cotana, F. De Giorgio, A.L. Pisello, How subjective and non-physical parameters affect occupants' environmental comfort perception, Energy and Buildings 178 (2018) 107-129

[42] ASHRAE, ANSI/ASHRAE Standard 55 - Thermal Environmental Conditions for Human Occupancy, ASHRAE, Atlanta, GA, 2017.

[43] ISO 7726, Ergonomics of the thermal environment. Instruments for measuring physical quantities, International Organization for Standardization (ISO), Geneva, 2001.

[44] ISO 7730, Moderate Thermal Environments- Determination of the PMV and PPD Indices and Specifications of the Conditions for Thermal Comfort., International Organization for Standardization (ISO), Geneva, 2006.

[45] ASHRAE, ASHRAE Fundamentals Handbook 2017 (SI Edition), American Society of Heating, Refrigerating, and Air-Conditioning Engineers, Atlanta, GA, USA, 2017.

[46] E. Ballantyne, R. Hill, J. Spencer, Probit analysis of thermal sensation assessments, International Journal of Biometeorology 21(1) (1977) 29-43

[47] W. Yang, N.H. Wong, S.K. Jusuf, Thermal comfort in outdoor urban spaces in Singapore, Building and Environment 59 (2013) 426-435. doi:https://doi.org/10.1016/j.buildenv.2012.09.008

[48] J. Spagnolo, R. de Dear, A field study of thermal comfort in outdoor and semi-outdoor environments in subtropical Sydney Australia, Building and Environment 38(5) (2003) 721-738. doi:http://dx.doi.org/10.1016/S0360-1323(02)00209-3

[49] N. Kántor, A. Kovács, Á. Takács, Seasonal differences in the subjective assessment of outdoor thermal conditions and the impact of analysis techniques on the obtained results, International Journal of Biometeorology 60(11) (2016) 1615-1635. doi:10.1007/s00484-016$1151-x$

[50] K. Pantavou, M. Santamouris, D. Asimakopoulos, G. Theoharatos, Empirical calibration of thermal indices in an urban outdoor Mediterranean environment, Building and Environment 80 (2014) 283-292. doi:https://doi.org/10.1016/j.buildenv.2014.06.001

[51] R.-L. Hwang, T.-P. Lin, N.-J. Kuo, Field experiments on thermal comfort in campus classrooms in Taiwan, Energy and Buildings 38(1) (2006) 53-62. doi:https://doi.org/10.1016/j.enbuild.2005.05.001 
[52] S. Shooshtarian, I. Ridley, The effect of physical and psychological environments on the users thermal perceptions of educational urban precincts, Building and Environment 115 (2017) 182198. doi:http://dx.doi.org/10.1016/j.buildenv.2016.12.022

[53] S.L. Heng, W.T.L. Chow, How 'hot' is too hot? Evaluating acceptable outdoor thermal comfort ranges in an equatorial urban park, International Journal of Biometeorology (2019). doi:10.1007/s00484-019-01694-1

[54] W. Yang, N. Wong, G. Zhang, A comparative analysis of human thermal conditions in outdoor urban spaces in the summer season in Singapore and Changsha, China, International Journal of Biometeorology 57(6) (2013) 895-907. doi:10.1007/s00484-012-0616-9

[55] J. Nakano, S.-I. Tanabe, Thermal comfort and adaptation in semi-outdoor environments, Ashrae Transactions 110 (2004) 543

[56] J. Nicol, C. Doré, J. Weiner, D. Lee, S. Prestidge, M. Andrews, Comfort studies of rail passengers, Occupational and Environmental Medicine 30(4) (1973) 325-334

[57] W. Macfarlane, Thermal comfort studies since 1958, Architectural Science Review 21(4) (1978) 86-92

[58] D.A. McIntyre, Seven point scales of warmth, Building Services Engineering Research and Technology 45 (1978) 215-226

[59] M. Schweiker, X. Fuchs, S. Becker, M. Shukuya, M. Dovjak, M. Hawighorst, J. Kolarik, Challenging the assumptions for thermal sensation scales, Building Research \& Information 45(5) (2017) 572-589. doi:10.1080/09613218.2016.1183185

[60] S.Q.d.S. Hirashima, A. Katzschner, D.G. Ferreira, E.S.d. Assis, L. Katzschner, Thermal comfort comparison and evaluation in different climates, Urban Climate 23 (2018) 219-230. doi:https://doi.org/10.1016/j.uclim.2016.08.007

[61] N. Kántor, J. Unger, Á. Gulyás, Subjective estimations of thermal environment in recreational urban spaces-Part 2: international comparison, International Journal of Biometeorology 56(6) (2012) 1089-1101. doi:10.1007/s00484-012-0564-4

[62] A.P. Gagge, J.A.J. Stolwijk, J.D. Hardy, Comfort and thermal sensations and associated physiological responses at various ambient temperatures, Environmental Research 1(1) (1967) 120. doi:http://dx.doi.org/10.1016/0013-9351(67)90002-3

[63] P.O. Fanger, Thermal comfort analysis and applications in environmental engineering, McGraw-Hill, New York, 1970.

[64] R.J. de Dear, A. Auliciems, Validation of the predicted mean vote model of thermal comfort in six Australian field studies, ASHRAE transactions 91(2B) (1985) 452-468 
[65] D. Lai, D. Guo, Y. Hou, C. Lin, Q. Chen, Studies of outdoor thermal comfort in northern China, Building and Environment 77 (2014) 110-118

[66] E.L. Krüger, T.J.V. Silva, S.Q. da Silveira Hirashima, E.G. da Cunha, L.A. Rosa, Calibrating UTCI'S comfort assessment scale for three Brazilian cities with different climatic conditions, International Journal of Biometeorology (2020). doi:10.1007/s00484-020-01897-x

[67] M. Fountain, G. Brager, R. de Dear, Expectations of indoor climate control, Energy and Buildings 24(3) (1996) 179-182. doi:https://doi.org/10.1016/S0378-7788(96)00988-7

[68] M.A. Humphreys, M. Hancock, Do people like to feel 'neutral'?: Exploring the variation of the desired thermal sensation on the ASHRAE scale, Energy and Buildings 39(7) (2007) 867-874. doi:http://dx.doi.org/10.1016/j.enbuild.2007.02.014

[69] S. Shahzad, J. Brennan, D. Theodossopoulos, J.K. Calautit, B.R. Hughes, Does a neutral thermal sensation determine thermal comfort?, Building Services Engineering Research and Technology 39(2) (2018) 183-195

[70] T. Huang, J. Li, Y. Xie, J. Niu, C.M. Mak, Simultaneous environmental parameter monitoring and human subject survey regarding outdoor thermal comfort and its modelling, Building and Environment 125 (2017) 502-514. doi:https://doi.org/10.1016/j.buildenv.2017.09.015

[71] M. Rutty, D. Scott, Bioclimatic comfort and the thermal perceptions and preferences of beach tourists, International Journal of Biometeorology 59(1) (2015) 37-45. doi:10.1007/s00484-0140820-x

[72] F. Canan, I. Golasi, S. Falasca, F. Salata, Outdoor thermal perception and comfort conditions in the Köppen-Geiger climate category BSk. one-year field survey and measurement campaign in Konya, Turkey, Science of The Total Environment (2020) 140295. doi:https://doi.org/10.1016/j.scitotenv.2020.140295

[73] Y. Wang, R. de Groot, F. Bakker, H. Wörtche, R. Leemans, Thermal comfort in urban green spaces: a survey on a Dutch university campus, International Journal of Biometeorology 61(1) (2017) 87-101. doi:10.1007/s00484-016-1193-0

[74] A. Middel, N. Selover, B. Hagen, N. Chhetri, Impact of shade on outdoor thermal comforta seasonal field study in Tempe, Arizona, International Journal of Biometeorology 60(12) (2016) 1849-1861. doi:10.1007/s00484-016-1172-5

[75] R. de Dear, A. Auliciems, Airconditioning in Australia II-user attitudes, Architectural Science Review 31(1) (1988) 19-27

[76] T.-P. Lin, Thermal perception, adaptation and attendance in a public square in hot and humid regions, Building and Environment 44(10) (2009) 2017-2026. doi:http://dx.doi.org/10.1016/j.buildenv.2009.02.004 
[77] M. Hawighorst, M. Schweiker, A. Wagner, The psychology of thermal comfort: Influences of thermo-specific self-efficacy and climate sensitiveness, in: M. Loomans (Ed.) Proceedings of the Healthy Buildings Europe, EindhovenThe Psychology of Thermal Comfort: Influences of Thermo-specific Self-Efficacy and Climate Sensitiveness, Eindhoven, The Netherlands, 2015, pp. 97-98.

[78] S. Karjalainen, Thermal comfort and gender: a literature review, Indoor Air 22(2) (2012) 96109. doi:10.1111/j.1600-0668.2011.00747.x

[79] C.-H. Tung, C.-P. Chen, K.-T. Tsai, N. Kántor, R.-L. Hwang, A. Matzarakis, T.-P. Lin, Outdoor thermal comfort characteristics in the hot and humid region from a gender perspective, International Journal of Biometeorology 58(9) (2014) 1927-1939. doi:10.1007/s00484-014-07957

[80] Y. Peng, T. Feng, H.J.P. Timmermans, Expanded comfort assessment in outdoor urban public spaces using Box-Cox transformation, Landscape and Urban Planning 190 (2019) 103594. doi:https://doi.org/10.1016/j.landurbplan.2019.103594

[81] R. de Dear, Revisiting an old hypothesis of human thermal perception: alliesthesia, Building Research \& Information 39(2) (2011) 108-117

[82] T. Parkinson, R. de Dear, Thermal pleasure in built environments: physiology of alliesthesia, Building Research \& Information 43(3) (2015) 288-301

[83] M. Nikolopoulou, Outdoor thermal comfort, Frontiers in bioscience 3 (2011) 1552-1568

[84] M.M. Baruti, E. Johansson, J. Åstrand, Review of studies on outdoor thermal comfort in warm humid climates: challenges of informal urban fabric, International Journal of Biometeorology 63(10) (2019) 1449-1462. doi:10.1007/s00484-019-01757-3

[85] R.J. de Dear, G.S. Brager, Developing an adaptive model of thermal comfort and preference, ASHRAE Transactions 104 (1998) 145-167

[86] M.A. Humphreys, J.F. Nicol, Do People Like to Feel "Neutral"? Response to the ASHRAE Scale of Subjective Warmth in Relation to Thermal Preference, Indoor and Outdoor Temperature/DISCUSSION, ASHRAE Transactions 110 (2004) 569-577

[87] ISO 10551, Ergonomics of the Thermal Environment - Assessment of the Influence of the Thermal Environment Using Subjective Judgement Scales, International Organization for Standardization, Geneva, 2019.

[88] S. Liu, N. Nazarian, J. Niu, M. Hart, R. de Dear, From thermal sensation to thermal affect: A multi-dimensional semantic space to assess outdoor thermal comfort, Building and Environment (2020) 107112. doi:https://doi.org/10.1016/j.buildenv.2020.107112 
[89] K. Lindner-Cendrowska, K. Błażejczyk, Impact of selected personal factors on seasonal variability of recreationist weather perceptions and preferences in Warsaw (Poland), International Journal of Biometeorology 62(1) (2018) 113-125. doi:10.1007/s00484-016-1220-1

[90] T.-P. Lin, A. Matzarakis, Tourism climate and thermal comfort in Sun Moon Lake, Taiwan, International Journal of Biometeorology 52(4) (2008) 281-290. doi:10.1007/s00484-007-0122-7

[91] P.K. Cheung, C.Y. Jim, Improved assessment of outdoor thermal comfort: 1-hour acceptable temperature range, Building and Environment 151 (2019) 303-317. doi:https://doi.org/10.1016/j.buildenv.2019.01.057

[92] S. Shooshtarian, I. Ridley, The effect of individual and social environments on the users thermal perceptions of educational urban precincts, Sustainable Cities and Society 26 (2016) 119133

[93] J. Huang, C. Zhou, Y. Zhuo, L. Xu, Y. Jiang, Outdoor thermal environments and activities in open space: an experiment study in humid subtropical climates, Building and environment 103 (2016) 238-249

[94] E. Sharifi, J. Boland, Limits of thermal adaptation in cities: outdoor heat-activity dynamics in Sydney, Melbourne and Adelaide, Architectural Science Review 61(4) (2018) 191-201. doi: $10.1080 / 00038628.2018 .1482824$

[95] P. Höppe, Different aspects of assessing indoor and outdoor thermal comfort, Energy and Buildings 34(6) (2002) 661-665. doi:http://dx.doi.org/10.1016/S0378-7788(02)00017-8

[96] H. Zhang, E. Arens, D. Kim, E. Buchberger, F. Bauman, C. Huizenga, Comfort, perceived air quality, and work performance in a low-power task-ambient conditioning system, Building and Environment 45(1) (2010) 29-39. doi:https://doi.org/10.1016/j.buildenv.2009.02.016

[97] W. Pasut, H. Zhang, E. Arens, S. Kaam, Y. Zhai, Effect of a heated and cooled office chair on thermal comfort, HVAC\&R Research 19(5) (2013) 574-583

[98] W. Pasut, E. Arens, H. Zhang, Y. Zhai, Enabling energy-efficient approaches to thermal comfort using room air motion, Building and Environment 79 (2014) 13-19. doi:https://doi.org/10.1016/j.buildenv.2014.04.024

[99] I. Golasi, F. Salata, E. de Lieto Vollaro, M. Coppi, Complying with the demand of standardization in outdoor thermal comfort: a first approach to the Global Outdoor Comfort Index (GOCI), Building and Environment 130 (2018) 104-119

[100] Y. Peng, T. Feng, H. Timmermans, A path analysis of outdoor comfort in urban public spaces, Building and Environment 148 (2019) 459-467. doi:https://doi.org/10.1016/j.buildenv.2018.11.023 
[101] Z. Tan, S.C. Chung, A.C. Roberts, K.K.-L. Lau, Design for climate resilience: influence of environmental conditions on thermal sensation in subtropical high-density cities, Architectural Science Review 62(1) (2019) 3-13

[102] C.K.C. Lam, H. Yang, X. Yang, J. Liu, C. Ou, S. Cui, X. Kong, J. Hang, Cross-modal effects of thermal and visual conditions on outdoor thermal and visual comfort perception, Building and Environment 186 (2020) 107297. doi:https://doi.org/10.1016/j.buildenv.2020.107297

[103] D. Watson, L.A. Clark, A. Tellegen, Development and validation of brief measures of positive and negative affect: The PANAS scales, Journal of Personality and Social Psychology 54(6) (1988) 1063-1070. doi:10.1037/0022-3514.54.6.1063

[104] D.M. McNair, M. Lorr, L.F. Droppleman, Revised manual for the Profile of Mood States, Educational and Industrial Testing Services, San Diego, CA, 1992.

[105] L. Lan, Z. Lian, Use of neurobehavioral tests to evaluate the effects of indoor environment quality on productivity, Building and Environment 44(11) (2009) 2208-2217. doi:https://doi.org/10.1016/j.buildenv.2009.02.001

[106] K. Healey, M. Webster-Mannison, Exploring the influence of qualitative factors on the thermal comfort of office occupants, Architectural Science Review 55(3) (2012) 169-175. doi:10.1080/00038628.2012.688014

[107] A.-M. Sadick, A. Roetzel, M. DeKay, A.N. Kidd, V. Whittem, Reliability of human environmental "sensors": Evidence from first- and third-person methods, Building and Environment (2020) 107303. doi:https://doi.org/10.1016/j.buildenv.2020.107303 